\title{
BMJ Open Sustaining community-based interventions for people affected by dementia long term: the SCI-Dem realist review
}

\author{
Thomas Morton (D , , Geoff Wong, ${ }^{2}$ Teresa Atkinson, ${ }^{1}$ Dawn Brooker ${ }^{1}$
}

To cite: Morton T, Wong G, Atkinson $\mathrm{T}$, et al. Sustaining community-based interventions for people affected by dementia long term: the SCl-Dem realist review. BMJ Open 2021;11:e047789. doi:10.1136/ bmjopen-2020-047789

- Prepublication history and additional online supplemental material for this paper are available online. To view these files, please visit the journal online. To view these files, please visit the journal online (http://dx.doi.org/10.1136/ bmjopen-2020-047789)

Received 08 December 2020 Accepted 09 April 2021
Check for updates

(c) Author(s) (or their employer(s)) 2021. Re-use permitted under CC BY-NC. No commercial re-use. See rights and permissions. Published by BMJ.

${ }^{1}$ Association for Dementia Studies, University of Worcester, Worcester, UK

${ }^{2}$ Nuffield Department of Primary Care Health Sciences, Oxford University, Oxford, UK

Correspondence to

Dr Dawn Brooker;

d.brooker@worc.ac.uk

\section{ABSTRACT}

Objectives Community-based support for people with earlier-stage dementia and their care partners, such as regularly meeting groups and activities, can play an important part in postdiagnostic care. Typically delivered piecemeal in the UK, by a variety of agencies with inconsistent funding, provision is fragmented and many such interventions struggle to continue after only a short start-up period. This realist review investigates what can promote or hinder such interventions in being able to sustain long term.

Methods Key sources of evidence were gathered using formal searches of electronic databases and grey literature, together with informal search methods such as citation tracking. No restrictions were made on article type or study design; only data pertaining to regularly meeting, ongoing, community-based interventions were included. Data were extracted, assessed, organised and synthesised and a realist logic of analysis applied to trace context-mechanism-outcome configurations as part an overall programme theory. Consultation with stakeholders, involved with a variety of such interventions, informed this process throughout.

Results Ability to continually get and keep members; staff and volunteers; the support of other services and organisations; and funding/income were found to be critical, with multiple mechanisms feeding into these suboutcomes, sensitive to context. These included an emphasis on socialising and person-centredness; lowering stigma and logistical barriers; providing support and recognition for personnel; networking, raising awareness and sharing with other organisations, while avoiding conflict; and skilled financial planning and management.

Conclusions This review presents a theoretical model of what is involved in the long-term sustainability of community-based interventions. Alongside the need for longer-term funding and skilled financial management, key factors include the need for stigma-free, person-centred provision, sensitive to members' diversity and social needs, as well as the need for a robust support network including the local community, health and care services. Challenges were especially acute for small scale and rural groups.

\section{Strengths and limitations of this study}

- This review brings together transferable learning from a wide range of intervention types on a topic that has received little formal, integrated research attention, to deepen our understanding on how such interventions could be implemented and supported to sustain more universally and consistently across the sector.

- This review's realist approach is well suited to accommodate and account for the complexity of such 'real life' intervention programmes, as implemented under different conditions in different settings, to extract transferable conclusions.

- This review was designed to gather evidence regarding how interventions can be sustained, not on the efficacy/effectiveness of interventions of this type, hence conclusions regarding the latter are beyond its scope.

- Literature was limited as this research question is not commonly the main focus of study in dementia care research.

- Not all data were equal in depth and detail or the highest empirical rigour, rather they contributed together in a way that was useful to an overall programme theory that will benefit from further refinement and revision with empirical testing in subsequent research.

\section{INTRODUCTION}

Supporting people with dementia and their carers to live as well as possible in their communities, with timely psychosocial support, is a global public health goal, ${ }^{1}$ though remains a challenging aspiration in many countries. In the UK, with an ageing population $^{2}$ and increasing pressure on already-stretched health services, ${ }^{3}$ policy has for some time pointed to the need to move towards a model of social care where more people are cared for and supported at home, in the community. Improving provision of early, postdiagnosis support, support for family carers and better integrated care 
(involving the voluntary and independent sectors)—all in a more dementia-friendly community environment-are contemporary UK Government priorities for dementia care. $^{4}$

Support following a diagnosis of dementia is patchy, ${ }^{4}$ however, with families in some areas lacking any formal proactive support for those with less severe symptoms beyond occasional contact with primary care and third sector. There are significant gaps in social care for people affected by dementia across the UK. ${ }^{5-7}$ Multiple recent reports describe a climate where the state of social care provision-mainly delivered piecemeal by private and third-sector organisations-is 'precarious and dysfunctional' in many parts of the country ${ }^{6}$ and in some areas has 'broken down' creating 'care deserts'. There is an associated reliance on informal carers (eg, family members) but there is a growing recognition that informal carers' own health and well-being is often negatively impacted by their caring activities. ${ }^{6}$ The detrimental health impact of social isolation and loneliness is also increasingly being recognised ${ }^{89}$ with survey data revealing nearly $60 \%$ of people living with dementia report loneliness, isolation and losing touch with people in their lives since diagnosis, around a quarter feeling they are not part of their community and that people avoid them. ${ }^{7}$ Family carers can also be subject to such loneliness and isolation. ${ }^{10}$ This situation has only been exacerbated by the recent impact of COVID-19, ${ }^{11}$ bringing the need for groups and activities that provide social connection and support for people and families affected by dementia into stark relief.

There have been various attempts to mitigate these challenges in communities across the country, in the form of groups and activities for people with dementia and family carers. These aim to serve a number of functions: peer support, companionship and help for people to reintegrate with their communities; delivery of professional support, psychosocial interventions and physical exercise; a point of contact, signposting and referral for other services; or raising awareness and acting as a dementiafriendly community hub. The benefits of such communitybased initiatives are now being recognised. ${ }^{12-16}$ There is evidence that regular social activity, where people are able to leave their homes and gather together in a communal setting on a frequent and ongoing basis, can be helpful both for people living with dementia and the people who care for them. ${ }^{12} 1317-19$ With care systems unprepared for the forecasted UK doubling of the number of people living with dementia (1.6 million) and tripling of social care costs by $2040,{ }^{20}$ improving provision of evidencebased community initiatives for people with dementia, and their families, is imperative. ${ }^{12-162122}$ However, even prior to the 2020 pandemic restrictions, such initiatives, groups and activities already faced a variety of challenges with long-term sustainability. These challenges and how to meet them are much talked about in the dementia care policy, rhetoric and practice arenas but have received very little research attention.
This realist review aims to deepen our understanding of what can help or hinder the long-term sustainability of regularly meeting, place-based community interventions, such as groups and activities, for people affected by dementia. It aims to use data gathered as the basis of evidence-informed recommendations for policy and practice.

\section{METHODS}

This review was conducted from December 2018 to December 2020. A project protocol was registered with PROSPERO in March 2019 ${ }^{23}$ and the protocol was published in this journal in June 2019. ${ }^{24}$

The realist review is an interpretive, theory-driven approach to synthesising evidence from a range of sources, including qualitative, quantitative and mixed-methods research. ${ }^{25}$ This approach is designed to accommodate and account for the complexity of 'real-life' intervention programmes, as implemented under different conditions in different settings, aiming to explain how and why context can influence outcomes. ${ }^{26}$ Hence it is well suited to extracting transferable lessons from reviewing the functioning and success (or otherwise) of a range of community-based interventions for people affected by dementia, as these are likely to involve a high level of complexity and be responsive to contextual factors which are likely to vary considerably from intervention to intervention. Data were gathered and synthesised, with a realist logic of analysis applied to identify causal chains involving different contexts, mechanisms and outcomes that can in turn affect an initiative's long-term sustainability. We define context as the conditions that trigger or modify the behaviour of mechanisms; ${ }^{27}$ mechanisms are the usually-hidden processes that generate outcomes, defined as 'underlying entities, processes or structures which operate in particular contexts to generate outcomes of interest. ${ }^{28}$; outcomes can be 'either intended or unintended and can be proximal, intermediate or final ${ }^{27}$ and in this review refer to any identifiable result (of the interaction between contexts and mechanisms) that can directly have a bearing on an intervention's ability to sustain long term.

Our review followed Pawson's five iterative stages ${ }^{29}$ as outlined below.

\section{Step 1: locating existing theories}

This initial step was to identify and gather existing ideas around what can help or hinder the sustainability of a group or activity, from those who have first-hand experience of them. In line with realist review guidelines (RAMESES: Realist and Meta-narrative Evidence Syntheses Evolving Standards), ${ }^{29}$ stakeholders were contacted by TA and TM and consulted for input at points throughout the project. These stakeholders were lay experts involved with community-based interventions in various capacities, whether commissioning, leading, running, supporting or attending. In the first instance, 
a workshop was held in March 2019 with a group of 13 invited stakeholders to gather their content expertise on barriers and facilitators to engagement and sustainability. Eight others were subsequently consulted by TM individually, in person, by telephone or by email. Input was also taken by TA and TM from members and facilitators of various local Dementia Engagement and Empowerment Project ${ }^{30}$ groups at a national meeting in June 2019, and TM also visited three community groups in Herefordshire, Oxfordshire and Wolverhampton. In addition, an exploratory search of the literature was conducted by TM, using informal methods such as citation tracking and snow-balling ${ }^{31}$ along with informal scoping searches ${ }^{32}$ and the gathering of relevant publications and materials recommended by stakeholders. Together, this contributed towards the building of an initial theoretical model, or programme theory, with the guidance of GW, prior to our main search, both to inform our formal search strategy and to be tested and refined by the data subsequently found. This model began as two diagrams (one regarding engagement, one regarding sustainability), drawn up by TM and TA by batching issues raised at the March workshop, and possible links between them. These diagrams were then discussed, altered and added to iteratively over 4 months as new stakeholder input became available (these can be seen in online supplemental file $1)$. These diagrams were speculative so kept deliberately broad and fluid in focus, as a work in progress. Detailed analysis of possible context-mechanism-outcome configurations (CMOCs) was not considered appropriate at this stage, as: (1) Not enough data had been gathered; (2) This would be both labour intensive and too limiting for a model whose purpose was only as a steering guide to inform the review proper, yet to be undertaken.

\section{Step 2: search for evidence \\ Formal search}

Formal searching activity took place between May and September 2019. A search strategy was designed, piloted and conducted by the research team with the guidance from an information specialist (CK) (see online supplemental file 2). The following databases were searched: Academic Search Complete; AMED; CINAHL; EMBASE; MEDLINE; ProQuest; PsycINFO; PubMed; Scopus and Social Care Online. In keeping with RAMESES guidelines, ${ }^{29}$ no restrictions were made on the type of article or study design eligible for inclusion, other than being more recent than 1990. Documents such as editorials, opinion pieces, information guides, publicity materials, newspaper and magazine articles, evaluation reports, $\mathrm{PhD}$ theses and research poster and slide presentations were included along with peer-reviewed journal articles, if found to be holding relevant information. Search terms were kept uniform across all databases and searching was carried out by looking for the occurrence of these within the title, abstract and key words of documents (or nearest equivalent) in each database. Database-specific defined keywords were not used as the types of intervention were not only very diverse but often without a common agreed terminology, hence using too narrowly-specified terms would have resulted in an unmanageably voluminous list of possible key words, without necessarily locating bettertargeted results, and could be limiting and misleading. In addition the nature of this review's research question is atypical in that it does not have an efficacy/effectiveness focus in common with many of its sources of data, hence manual screening was key in determining relevance. A disadvantage of this was that we had to accept a higher ratio of irrelevant search hits which then had to be excluded through manual screening of title and abstract.

After removing duplicates, records were screened by title and abstract by TM using the eligibility criteria, ensuring interventions covered were those targeted towards people with dementia and their families living in the community, that brought people together physically and met on a frequent, regular and an ongoing basis (these criteria are outlined in full detail in online supplemental file 3). Interventions exclusively for those with severe dementia at advanced stages were excluded as these were not the focus of this review. Those with severe dementia have high needs and are less likely to be living independently in the community, hence by their nature community-based interventions where people meet outside of their home are likely to serve those who are towards the start of their dementia journey rather than those at an advanced stage, and are distinct from more acute care.

Full text of documents were then obtained of the remaining records, and again screened by close reading against the eligibility criteria by TM. A 10\% random subsample of was reviewed independently at each of these stages by a second reviewer (TA) with disagreements recorded and resolved by discussion. Informal searching continued iteratively alongside the formal search and in response to articles found in it, congruent with the realist review process which allows searching to be revised as necessary as the review progresses. ${ }^{29}$ In certain cases, documents regarding on interventions that met only some, not all, of the inclusion criteria were included, if found to contain information on hypothesised mechanisms with reason to believe such mechanisms may function similarly or analogously in types of intervention that are closely related. ${ }^{33}$

\section{Steps 3 and 4: article selection, data extraction and organisation} Figure 1 shows a Preferred Reporting Items for Systematic Reviews and Meta-Analyses diagram outlining the full screening and selection process.

Following screening and close-reading of full texts for eligibility, full texts of the remaining 122 articles were loaded into NVivo qualitative data analysis software to help locate and categorise (code) relevant sections of text containing data regarding contexts, mechanisms or outcomes pertinent to the long-term sustainability of the intervention they described. Coding was both inductive (codes created in response to data as found) and deductive (codes created in advance, informed by the 


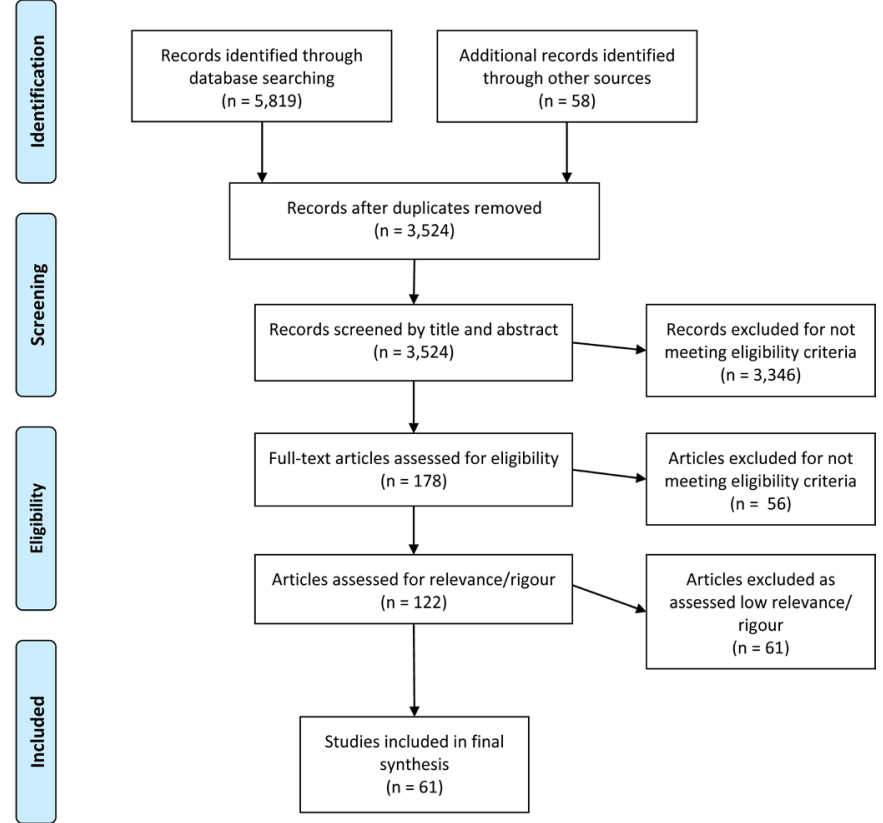

Figure 1 PRISMA flow diagram. PRISMA, Preferred Reporting Items for Systematic Reviews and Meta-Analyses.

initial programme theory) and carried out by TM (An overview of top-level 'parent' codes can also be seen in online supplemental file 1); deductive codes can be identified in that they mirror the headings of the initial model diagrams). The characteristics of the articles were also extracted separately into an EXCEL spreadsheet.

During this extraction and organisation process, more fine-grained assessments of relevance (to answering the research question) and rigour (the trustworthiness and credibility of the data and its source) ${ }^{25} 34$ were made by TM, with a random sample of $10 \%$ of articles again selected, assessed independently and discussed with TA. The data contained in an article was assessed on its own merits, not on the merits of the paper or study as a whole. This is because it was recognised that poorly designed or conducted research may still contain good quality 'nuggets' of information for a realist review, ${ }^{3435}$ or a document meeting inclusion criteria may not contain any relevant data. Due to the variety and breadth of the type of article included in the review, a standardised relevance and rigour assessment tool that would be appropriate in all cases was impossible to design. ${ }^{25}$ Rather a set of general principles was agreed to guide a 'traffic light' assessment system of low, medium and high relevance, and low, medium and high rigour (see online supplemental file 3 for detail). Reasons for each assessment were outlined and logged for each article and compared with each other to ensure consistency. Ambiguous cases of relevance or rigour were discussed with the wider project team as they arose. A decision was made by the project team to exclude articles assessed to have data of low relevance or low rigour to ensure a more robust dataset with which to build the final programme theory and CMOCs.
Step 5: synthesising the evidence and drawing conclusions

Once data from the remaining articles were extracted and categorised, key outcome themes were identified by discussion with the whole team. These themes and categories were presented to the stakeholders for comment and feedback, to determine what was most important to focus on, if they felt anything had been overlooked and if any changes or refinements should be made. Four key outcome areas (getting and keeping members, personnel, support of other organisations and funding/income) were settled on. Data were then organised under these headings in the form of 'If-then' statements that provided initial explanations of how, why, for whom and in which contexts these outcomes might arise, initially by TM but with input from DB and TA. These were then further refined, with guidance from GW, using a realist logic of analysis to identify cause-and-effect chains in the data and finally elaborated into CMOCs. ${ }^{29}$ Related CMOCs were then grouped together to create recommendations for practice or policy that also acted as a summary of the CMOCs found. Diagrams of the factors found affecting sustainability, and how they are likely to relate to each other within an overall programme theory, were also designed through team discussion and drawn by TM.

\section{Patient and public involvement}

The research question was developed during the authors' previous work with community interventions (eg, but not limited to, Meeting Centres) ${ }^{12}{ }^{13}$ and the practical problems encountered with sustaining such interventions expressed both by personnel and by members of the public attending. This review mainly involved the gathering of secondary data so did not involve patients or public directly as study participants. However, people with dementia, their family and friends, intervention staff and volunteers, and other community stakeholders were consulted as content experts throughout, informing the search strategy, data synthesis, development of materials and channels for dissemination. More information on our stakeholder consultation process can be found under step 1: locating existing theories and step 5: synthesising the evidence and drawing conclusions.

\section{RESULTS}

In total, 61 articles were coded to develop the CMOCs used to refine and expand our initial programme theory (see online supplemental file 4) for a detailed list of included articles). They were published between 1990 and 2020, and ranged in type: most were either peerreviewed journal articles (28) or formal reports/evaluations (18); information guides (8), news feature articles (3), doctoral theses (2) and conference presentation paraphernalia (2) were also analysed. About half of these articles (33) were authored (or coauthored) in the UK, consistent with a proportion being identified informally through UK-based stakeholders (see figure 2). Four articles had international authorship. Other countries 


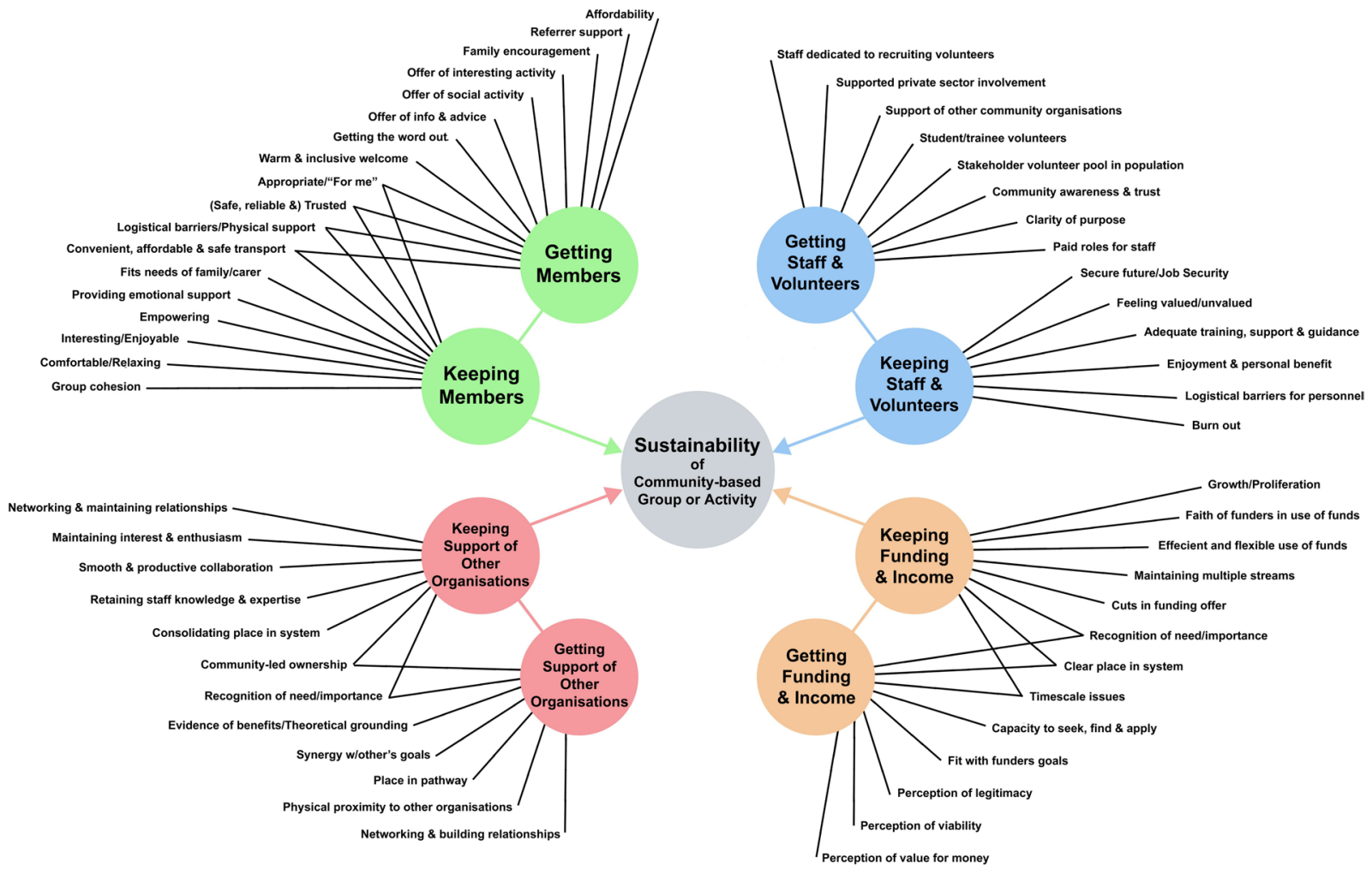

Figure 2 Factors affecting the sustainability of community-based groups and activities.

of origin (or co-origin) comprised the US (8), Netherlands (7), Germany (5), Canada (4), Italy (4), Norway (3), Poland (3), Australia (2), Ireland (2), Sweden (2), Chile (1), Japan (1), Portugal (1) and Thailand (1). The type of intervention discussed in these articles varied broadly, including: day centres/day care, social activities, sports and exercise initiatives, peer support groups, arts and crafts groups, singing and music groups, cognitive stimulation, gardening activities and other outdoor activities. Many interventions had multiple and overlapping elements, for example, a sports activity may have a social function, a drop-in day centre may have exercise and cognitive stimulation activities, or a craft club may have peer support built in. When an article's remit was general (for example community support services, outdoor activities, social and leisure activities or third sector groups), data were included from the article only if it was relevant to our programme theory and the kind of interventions outlined in the inclusion criteria (see online supplemental file 3).

Our analysis, together with stakeholder input, identified four critical areas affecting the sustainability of an intervention: members, staff and volunteers, support of other organisations and funding/income. These were each subdivided into 'getting' and 'keeping' outcomes in recognition of changes in focus over time regarding these areas, and likely different contexts and mechanisms involved as an intervention continues. Figure 2 shows an overview of factors leading to the getting and keeping of members, staff and volunteers, support of other organisations and funding/income, found in the article data (individual diagrams tracing factors for each critical area can be found in online supplemental file 5).

Our analysis of the data produced 201 CMOCs (outlined in full in online supplemental file 6), all covered by the above eight subdivisions. These CMOCs provide causal explanations relating to sustainability of communitybased groups and activities either at the level of the individual, organisation or wider. Due to the high number of CMOCs, they were further organised by grouping them under practical recommendations that could follow. These recommendations are not simply an end conclusion, but were also part of the data synthesising process, as they act as a way in which to categorise and summarise the large number of CMOCs. Examples of how several grouped CMOCs were related to a recommendation can be seen in table 1 .

\section{Recommendations for practice}

In total, 41 recommendations for practice were drawn from the CMOCs as can be seen in table 2.

Data regarding getting and keeping members was the most abundant and showed most consensus. As may be expected, boosting the motivation and understanding of potential referrers, while lowering bureaucratic and logistical barriers, was important to getting members (CMOC 10-CMOC 14; CMOC 31-CMOC 46; CMOC 64CMOC 65). Transport from home to venue was particularly key: not just its availability, but people's experiences of the accessibility, appropriateness and convenience of it (CMOC 10-CMOC 14). Other salient mechanisms involved how respected, valued and comfortable members 


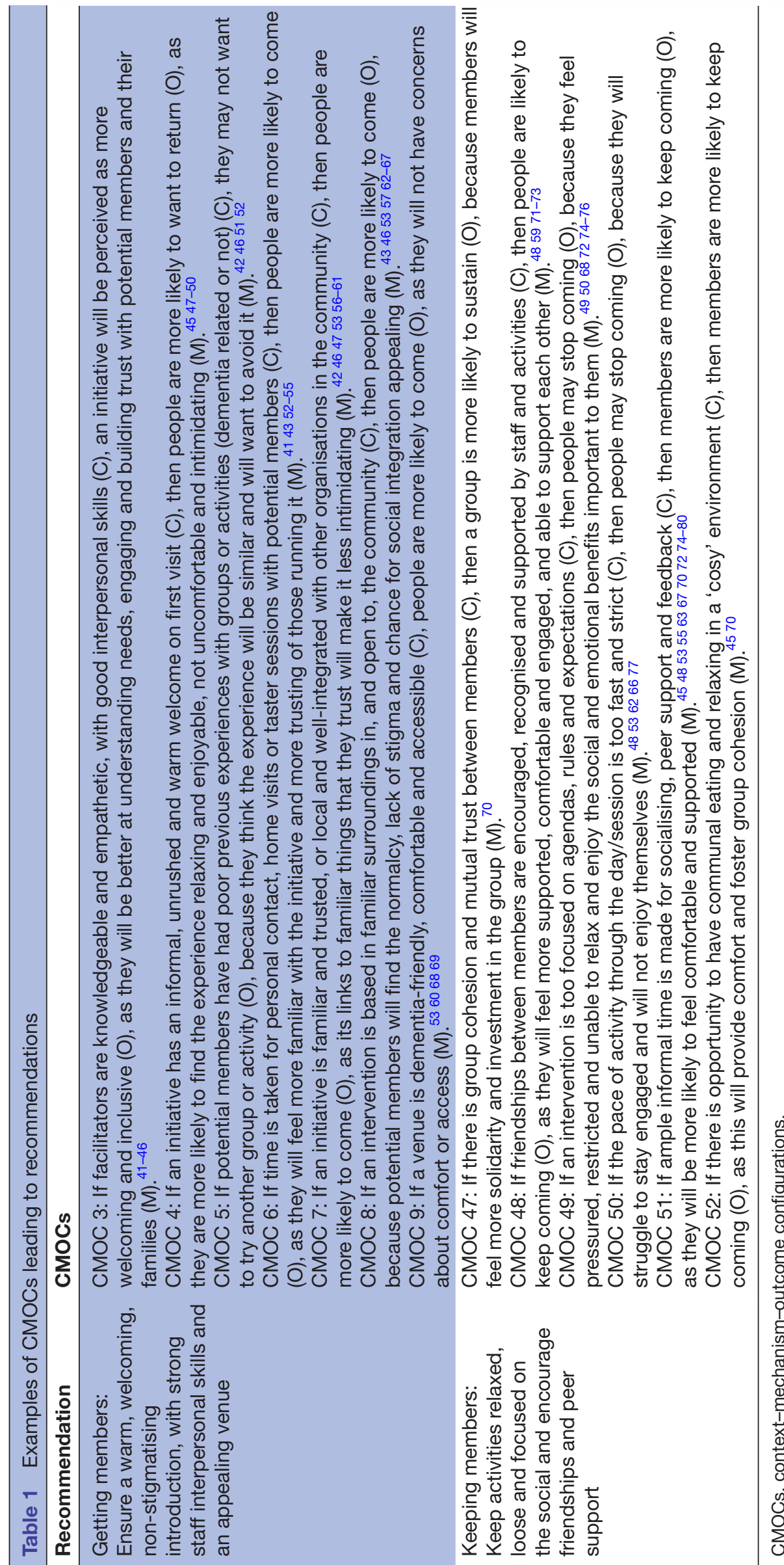




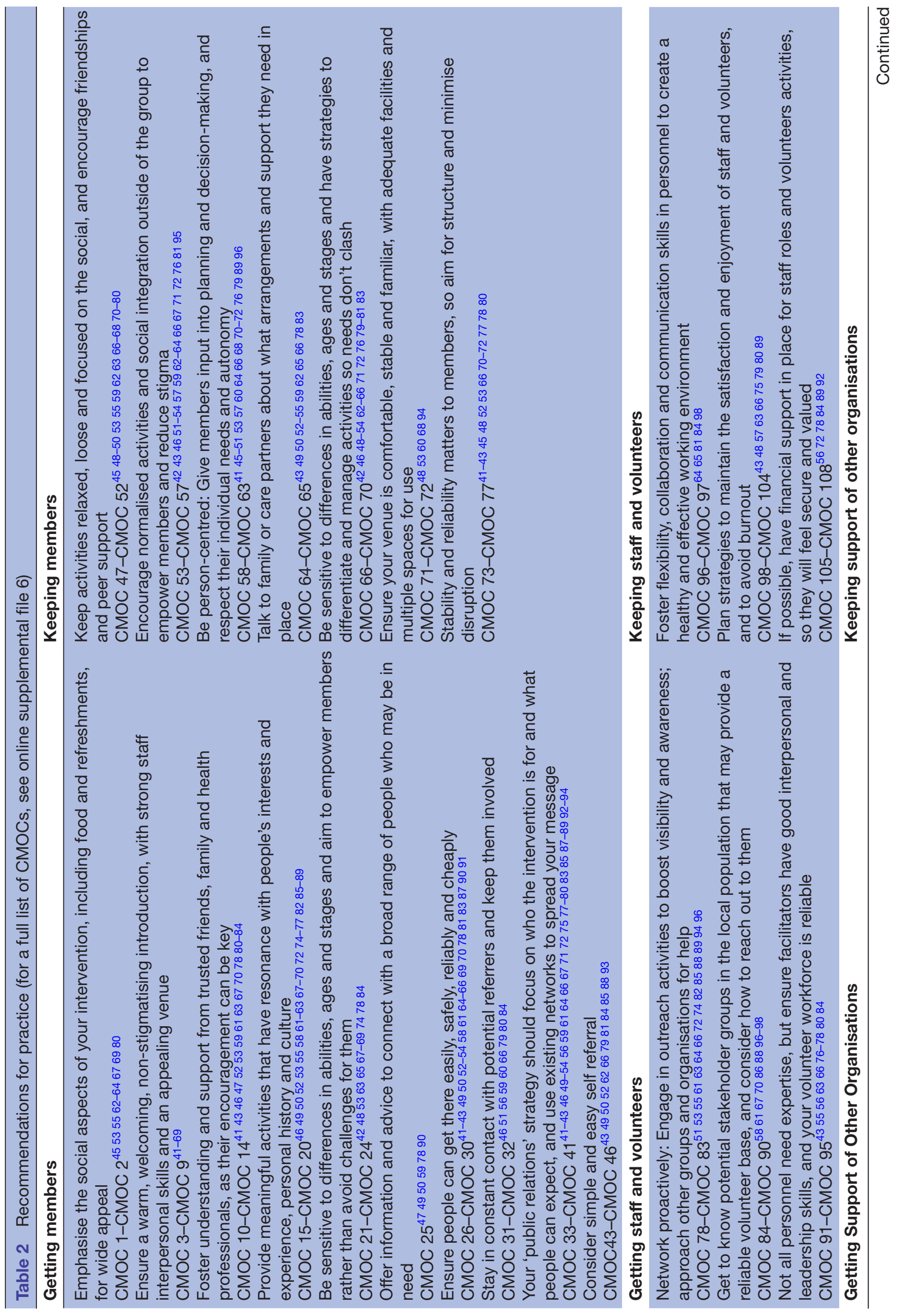




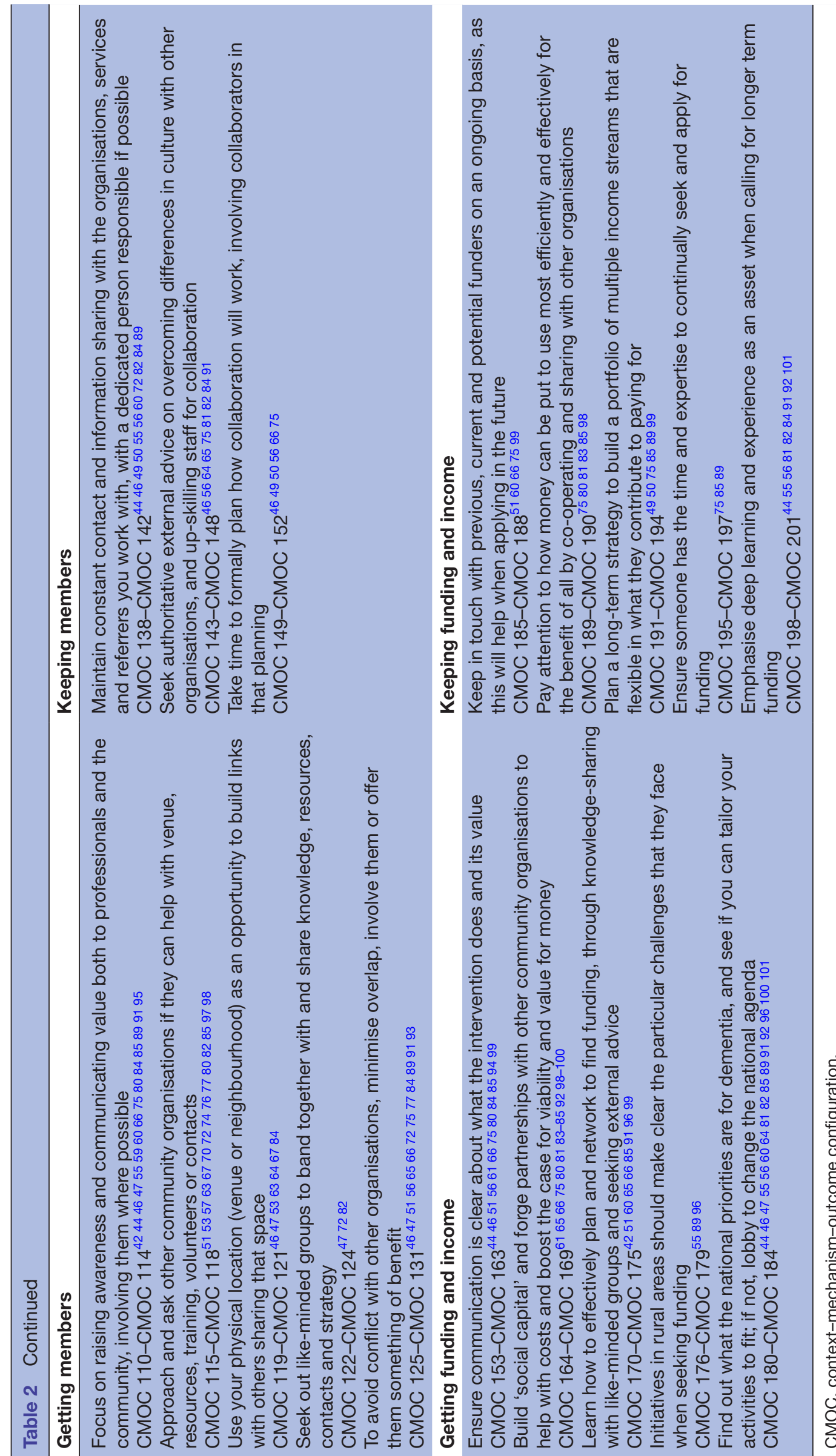

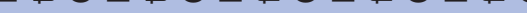

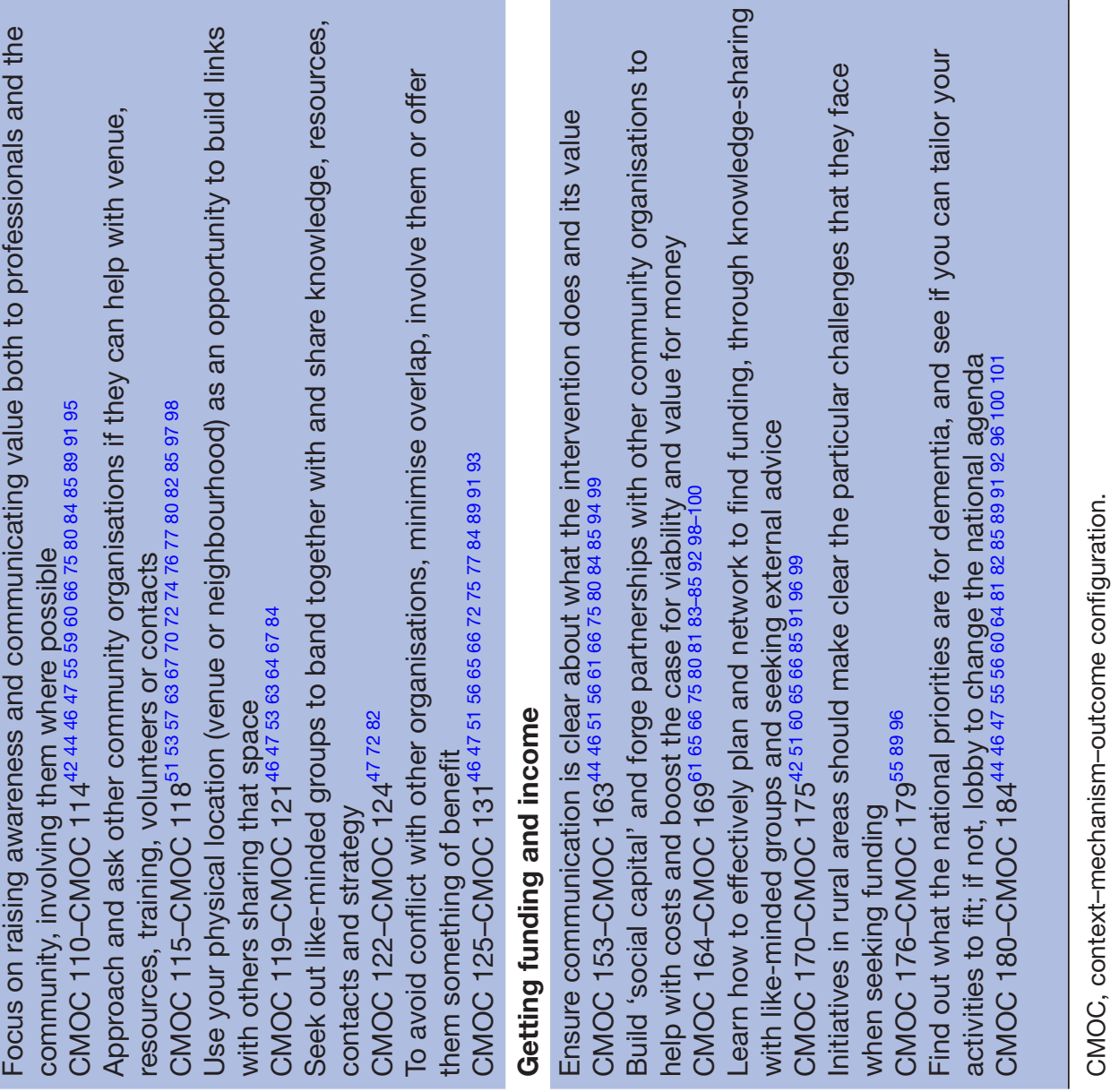


felt, or perceived they would feel should they attend: both for overcoming initial anxiety and stigma and fostering a happy, cohesive group (CMOC 3-CMOC 9; CMOC 15CMOC 24; CMOC 53-CMOC 63; CMOC 71-CMOC 72). Staff attitudes and a comfortable, accessible venue play a role in this, but also planned practices, such as involving members in decision making (CMOC 58-CMOC 63), differentiating activities for need and ability (CMOC 21CMOC 24; CMOC 66-CMOC 70) and ensuring enough opportunity and time for socialising (reported to be of high importance to people no matter what the intervention or activity) (CMOC 1-CMOC 2; CMOC 47-CMOC 52). The stability and reliability of an intervention was also important, though often at odds with nature of groups run informally with few personnel and unstable income (CMOC 73-CMOC 77). Overall, ensuring individual wants and needs are met-that people they feel they are gaining something useful and appropriate to them in particular-was important to keeping members long term (CMOC 47-CMOC 72).

Data regarding getting and keeping staff and volunteers were least abundant of the four critical outcome areas, though working with other organisations was frequently alluded to as helpful in finding personnel (CMOC 78CMOC 83). Data regarding skills of personnel were largely around the role of communication and collaboration in creating an encouraging and effective environment for staff and volunteers (CMOC 84-CMOC 97). Context was key with regards to the availability of potential volunteers in the local population, as this could be very different depending on location (eg, rural or urban), with different likely mechanisms requiring different approaches to finding and encouraging volunteers from different demographic groups (CMOC 84-CMOC 90). With regard to keeping volunteers, issues raised included the importance of maintaining work satisfaction and avoiding burnout, and having financial support available (CMOC 98-CMOC 108).

Getting and keeping support of other organisations, such as other community groups, health and social care services, third sector bodies, local authorities and local businesses was a widely recurring theme in the data. Actively involving other organisations, minimising overlap, sharing knowledge and resources and offering something of benefit were all ways to encourage them to feel invested in supporting an intervention rather than threatened or indifferent to it (CMOC 122-CMOC 131), in addition to proactive awareness raising and networking (CMOC 110-CMOC 121). Good collaboration planning (with expert advice on collaborative working), along with continual attention to maintaining communication, were strategies to avoid problems developing or loss of enthusiasm with partner organisations (CMOC 138-CMOC 152).

On getting and keeping funding and income, salient CMOCs again involved continual networking and communication, for the reason that this would support multiple mechanisms: by reducing costs through sharing and partnership; boosting visibility, legitimacy and value in the eyes of potential and existing funders; and helping to locate more funding and income opportunities (CMOC 153-CMOC 175; CMOC 185-CMOC 190). Data made some reference to the importance of strategic planning in finding and managing funds, with outside expertise and dedicated personnel helpful in carrying this out (CMOC 170-CMOC 175; CMOC 191-CMOC 197). While tailoring an intervention to national (and therefore funders') priorities may increase its chances of obtaining funding, this is not always possible or desirable for a group (CMOC 180-CMOC 184). Groups in rural areas particularly, or experienced groups unable to find anything but short-term solutions, may have to raise greater awareness with commissioners and policy-makers about the specific challenges that face them, and lobby for change to ensure better conditions for groups in their situation long term (CMOC 170-CMOC 179; CMOC 198-CMOC 201). For example, rural groups with a small number of members and personnel can struggle to meet funders demands, especially if put in competition with larger, well-resourced organisations.

\section{Recommendations for policy and commissioning}

In addition, 13 recommendations for policy-making and commissioning were also drawn (see box 1), for the most part mirroring those for practice and drawing on the same CMOCs.

The final recommendation covers CMOCs unique to policy-making and commissioning, highlighting issues such as the detrimental effect of a disjoin between national policy and local need on an intervention finding support (as by adhering to one they will neglect the other) (CMOC 132). Practices that could benefit the sustainability of community interventions included ring-fencing funding specifically for dementia-targeted community initiatives; commissioning health and social care services to work with community initiatives; and developing health pathways around existing community networks (CMOC 133-CMOC 135). National and official organisations can also encourage a more strategic, joined up direction regarding community-based dementia support by showing leadership in working with smaller, local initiatives and support for potential private sector partners (CMOC 136-CMOC 137).

\section{DISCUSSION}

\section{Summary of findings}

Being able to continually get and hold on to members, staff and volunteers, the support of other services and organisations, and funding/income are the key factors in the long-term sustainability of a community-based intervention for people affected by dementia. There are multiple mechanisms that feed into these suboutcomes, sensitive to context. Ability to attract members was found to be driven by perceptions that a group or activity was 'for them', and expectations they would be 
Box 1 Recommendations for commissioning/policymaking (for a full list of context-mechanism-outcome configuration (CMOCs), see online supplemental file 6).

\section{Recommendations for commissioning/policy-making.}

Service users value the social side of an intervention highly, often more than the intervention or activity itself

CMOC 1-CMOC 2; CMOC 47-CMOC 53 334546 48-50 52-55 57 59 62-64 66-80

Service users need to feel an intervention is 'for them' to want to attend and keep attending

CMOC 15-CMOC 24; CMOC 66-CMOC 70 42 46-55 58 61-72 74-89

Lack of appropriate transport can be a major barrier to an intervention getting and keeping attendees

CMOC 26-CMOC 30; CMOC 65 $41-43495052-5561$ 62 64-66 697078 81-83 879091

Health and social care services that may refer to an intervention need incentive and guidance to do so

CMOC 42-CMOC 44; CMOC 134-CMOC $135^{525566748182848593}$

To retain staff and volunteers there needs to be adequate financial support in place for roles and activities

CMOC 105-CMOC $109^{55} 567278848992$

Established community organisations, including local authorities, can offer help in a number of ways to enable small-scale interventions to flourish

CMOC 115-CMOC $118^{515357636770727476778081859798}$

Access to advice on how to create partnerships, collaborate and overcome differences in culture with other organisations can help

CMOC 143-CMOC 148 465664657581828491

Access to advice on how to effectively plan and network to help find and manage funding and income can help

CMOC 170-CMOC 175 125160656685919699

Commissioners should be flexible and accommodating of the challenges facing small groups regarding evidence gathering

CMOC 176-CMOC $179^{5589} 96$

Policy-makers should ensure policy meets local needs with adequate, protected and accessible resources attached

CMOC 180-CMOC 182; CMOC 18444 46 475556606481828589919296100

Longer-term funding, with simplified application processes, would help

smaller initiatives with less capacity to continue

CMOC 195-CMOC $197^{758589}$

Longer term funding to support what is already being done will help retain and develop learning and practice on how best to meet local need CMOC 198-CMOC 20044 55568182849192

Authorities and national organisations can help create conditions that encourage support for small initiatives, though policy, leadership and commissioning

CMOC 132 - CMOC $137^{44525556647482}$

welcomed, respected and supported without stigma once attending, as well as having motivated referrers and low logistical barriers, including transport. Members are more likely to keep attending if they feel comfortable, at home, respected and empowered, with individual needs understood. Opportunity for socialising was found to be of high importance no matter what the intervention type, with stability and reliability also important. Networking and outreach were found to be important in getting staff and volunteers; feeling satisfied, valued and supported (including financially) was important in keeping them. Proactive measures to raise awareness and involve other organisations, avoiding conflict and sharing knowledge and resources, were found to help in securing essential support, though requiring significant maintenance through skilled communication, planning and working practices. Such networking and collaboration were found to be helpful in finding and securing funding and income, with skilled planning and management of multiple income streams helpful in sustaining long term. However, the often short-term nature of funding was found to be a barrier to retaining deep learning and experience, and disjoins between national policy and local need a barrier to securing both funding and wider support. Challenges in meeting funders' requirements and overcoming logistical barriers were especially acute for small-scale and rural groups.

\section{Strengths and limitations}

This review was designed to gather evidence regarding how regularly meeting community-based interventions for people affected by dementia can be sustained, not on the efficacy/effectiveness of interventions of this type, hence conclusions regarding the latter are beyond its scope. Literature was limited as this research question is not commonly the main focus of study in dementia care research. This meant some CMOCs arrived at were the result of abundant data sources, while others were not, hence the CMOCs here vary in robustness (see online supplemental file 6). While efforts were made to exclude data of low rigour (see online supplemental file 3), it is the nature of a realist review to include data from a variety of source types to build a theoretical model piecemeal; not all of the data were of equal depth and detail and many will not meet the highest level of empirical rigour, rather they contribute together in a way that is useful to the theoretical constructs that are the CMOCs and overall programme theory. ${ }^{33}$ The results of this review therefore should be taken as theory and sit in relation to other research: SCI-Dem provides a theoretical framework which can be put to the test and further refines by subsequent empirical research. ${ }^{33}$ The breadth of intervention types covered in this review is on the one hand a strength, as it has enabled the surfacing of commonalities in experience likely relevant to a wide range of real-world initiatives broadly in the same category; on the other hand, it means this review cannot be specific on certain details. An example is that little could be concluded on the costeffectiveness or economic functioning of the interventions covered, because details were both too scant and too specific to draw robust CMOCs that might usefully be applicable to others.

The practice of one researcher carrying out the bulk of article selection and data analysis, with a second researcher independently checking $10 \%$ at each stage for consistency (along with regular input and discussion with other members of the research team) is common in realist review, but nevertheless can be seen as a limitation, as in Cochrane-style systematic reviews double-screening by two reviewers independently is recommended for greater reliability of results. However, it should be noted 
realist review is a theory-driven interpretive approach with significant differences to more traditional forms of systematic review ${ }^{29}$; that is, the aim is to develop an evidence-informed theory rather than a comprehensive summation of all research data available on a particular research question.

\section{Recommendations and comparison with existing literature}

Recommendations for practice and policy are presented in table 2, Box 1, in the results section. However, they also highlight some common problems for which there may be no easy solution, for example, what to do in rural areas where public transport coverage is poor and potential members and volunteers are few and widespread, given that transport to venue is a key factor in getting and keeping members. The issue of whether interventions can be entirely self-sustaining or must rely on service-level agreements and grant funding is also a key one. This review suggests that costs can be reduced and income opportunities found by proactive networking and collaborative working; though rather than removing the need for grant funding, this is, more likely, useful in leveraging it, adding to it and helping it to go further. Recent research into whether social enterprises delivering adult social care services (not dementia specific) could be self-sustaining suggests that marketing is key but needs to focus on building relationships with stakeholders at multiple levels rather than adopting an approach akin to selling a product ${ }^{36}$ : networking and marketing are closely bound up with each other. Delivering social quality as well as service quality, having a hybrid workforce and diverse income streams to strengthen financial viability and reduce reliance on grants were also found to help. ${ }^{37}$ This review echoes all of these points with regards to dementiatargeted community-based interventions, in particular that interventions cannot sustain without a cultivated support network around them, as well as careful collaborative financial planning and management.

The emphasis found in this review on the value to members of social activity and a respectful, empowering person-centred approach, reinforces the benefits of community-based initiatives and regular social activity, both for people living with dementia and the people who care for them. ${ }^{12-19}$ However, the time-limited nature of most research in this area is unhelpful when seeking data on the long-term sustainability of such interventions, with a large number of articles excluded from this review due to this. Recent systematic reviews have found that psychosocial interventions tend to be short term, with short-term trials only measuring short-term impact, and a pressing need for more longer-term studies with larger sample sizes. ${ }^{14}{ }^{38}$ However, there is a 'chicken and egg' problem: if policy and commissioning is hesitant to support interventions unless there is evidence of robust statistical effects, then such interventions will struggle to sustain long enough, in enough abundance, to have the numbers to carry out the research required to produce that evidence. Equally, if research focuses only on efficacy/effectiveness without attention to the implementation process, and reporting of how costs were met and resources, personnel, and service users were found, then little can be learnt about sustaining them.

\section{Future research directions}

When drafting inclusion criteria for this review in 2018 it was decided to focus on interventions that brought people together to meet physically and socially, as distinct from community services that go into people's homes. It did not take into account virtual community activities or communities at-a-distance, which at the time seemed like a distinct niche. In 2020, however, this kind of activity became much more important, and integrated with the activities of existing community groups that met physically prior to the COVID-19 pandemic. With COVID-19 the landscape for community-based interventions has changed significantly, presenting further unprecedented challenges, but the need for groups that connect people socially remains acute. A recent study by the Alzheimer's Society ${ }^{11}$ revealed COVID-19 restrictions have had particularly negative impacts on the health and well-being of people affected by dementia and their carers, a finding echoed by the Alzheimer's Disease International's update report for $2020 .^{39}$ Restrictions have forced changes to routine, causing anxiety and strain in relationships; led to a reduction in skills and confidence; and increased pressure on home carers, not least through the erosion of support systems. ${ }^{40}$ Many support initiatives will have ceased operating either temporarily or permanently. As the effects of the pandemic continue to be felt, there is an urgent need for community-based interventions to find ways to keep going or re-establish quickly when emerging from COVID-19 restrictions. While the data used in this review predated the pandemic, it can provide a framework for new research to look at what sustainability-impacting elements have been affected and how. This review presents a theoretical model of the factors and mechanisms involved in the long-term sustainability of communitybased interventions. As such it is for further research to put this model to the test by comparing it empirically with real-world interventions going forward, which will further refine and add to this programme theory in a postpandemic climate.

\section{Twitter Thomas Morton @ThomasMortonADS}

Acknowledgements This project was funded by the Alzheimer's Society. Dr Shirley Evans (Association for Dementia Studies, University of Worcester) contributed to the writing of the protocol for this review. Clive Kennard (information specialist, University of Worcester), helped design, pilot and carry out the formal search. The authors would like to thank all those who shared their invaluable experience and contributed to advising and guiding this project as a stakeholder consultant: Alzheimer's Society research monitors Sue Comely, Maggie Ewer and Mair Graham; Philly Hare, Rachael Litherland, Damian Murphy and Rachel Niblock of DEEP/Innovations in Dementia, and all who attended the national meeting of DEEP groups at Wooodbrooke, Birmingham, July 2019; Teresa 'Dory' Davies, James McKillop and Dreane Williams of DEEP; Judith Baron and the Face It Together DEEP group; Jill Turley and The Buddies DEEP group; the Friends for Life DEEP group; Kim Badcock of Kim's Cafe (Denmead, Havant and Waterlooville, Hampshire); Jo Barrow and the Forget Me Not Lunch and Friendship Club (Bicester, Oxfordshire); Elizabeth Bartlett of the Laverstock Memory Support Group (Wiltshire); Shirley Bradley of 
Friends of the Elderly (Worcester); David Budd of Our Connected Neighbourhoods (Stirling); Di Burbidge of Liverpool DAA Diversity Sub-Group and Chinese Wellbeing (Liverpool); Kishwar Butt of the South Asian Ladies' Milaap Group (Wolverhampton); Michelle Candlish of Ceartas Advocacy (Kirkintilloch, East Dunbartonshire); Annette Darby of Brierly Hill Health and Social Care Centre (West Midlands); Sue Denman of Solva Care (Haverfordwest); Gerry Fouracres of Scrubditch Farm (Cirencester); Graham Galloway of Kirrie Connections (Kirriemuir, Angus); Reinhard Guss; Deborah Harrold of Agewell CIC (Oldbury, West Midlands); June Hennell; Jacoba Huizenga of Health and Social Care in Communities, Utrecht (Netherlands); Lynden Jackson of the Debenham Project (Suffolk); Ghazal Mazloumi of Trent Dementia Services Development Centre; Cheryl Poole of Leominster Meeting Centre; Anita Tomaszewski and Jennifer Williams of Me, Myself and I (Briton Ferry, Neath Port Talbot); Dame Louise Robinson; Droitwich Meeting Centre; Leominster Meeting Centre; the members of the UKMCSP National Reference Group; and Jennifer Bray, Shirley Evans, Nicola Jacobson-Wright, Chris Russell and Mike Watts of the Association for Dementia Studies, University of Worcester.

Contributors DB and TA conceptualised the study (along with SBE of the University of Worcester, who cowrote the protocol but does not meet the ICMJE criteria for authorship of this paper). GW and TM had input into developing the study (along with information specialist CK of the University of Worcester, who helped design the search strategy but does not meet the ICMJE criteria for authorship of this paper). The study was conducted by DB as principal investigator, TA as project manager, TM research associate and GW providing methodological expertise. TM wrote the first draft of this manuscript. GW, DB and TA critically contributed to and refined the originally submitted manuscript, as well as responses to reviewers' comments and the revised manuscript. All authors have read and approved the final manuscript.

Funding This work was supported by The Alzheimer's Society, Grant No: 402, AS-PG-17b-023. Gold Open Access Article Processing Charges met by the University of Worcester.

Disclaimer The views and opinions expressed therein are those of the authors and do not necessarily reflect those of the Alzheimer's Society.

Competing interests GW is Deputy Chair of the National Institute for Health Research Health Technology Assessment Prioritisation Committee: Integrated Community Health and Social Care (A).

Patient consent for publication Not required.

Provenance and peer review Not commissioned; externally peer reviewed.

Data availability statement Data are available on reasonable request. This study was a qualitative review of secondary data, hence no new primary dataset was generated. However, we can share more information on what data was extracted and how it was analysed if requested. Please contact TM at t.morton@worc.ac.uk, ORCID 0000-0001-8264-0834

Supplemental material This content has been supplied by the author(s). It has not been vetted by BMJ Publishing Group Limited (BMJ) and may not have been peer-reviewed. Any opinions or recommendations discussed are solely those of the author(s) and are not endorsed by BMJ. BMJ disclaims all liability and responsibility arising from any reliance placed on the content. Where the content includes any translated material, BMJ does not warrant the accuracy and reliability of the translations (including but not limited to local regulations, clinical guidelines, terminology, drug names and drug dosages), and is not responsible for any error and/or omissions arising from translation and adaptation or otherwise.

Open access This is an open access article distributed in accordance with the Creative Commons Attribution Non Commercial (CC BY-NC 4.0) license, which permits others to distribute, remix, adapt, build upon this work non-commercially, and license their derivative works on different terms, provided the original work is properly cited, appropriate credit is given, any changes made indicated, and the use is non-commercial. See: http://creativecommons.org/licenses/by-nc/4.0/.

\section{ORCID iD}

Thomas Morton http://orcid.org/0000-0001-8264-0834

\section{REFERENCES}

1 World Health Organisation. Global action plan on the public health response to dementia 2017-2025. Geneva: World Health Organisation, 2017. https://www.who.int/mental_health/neurology/ dementia/action_plan_2017_2025/en/

2 Office for National Statistics (ONS). Living longer: caring in later life. London: ONS, 2019. https://www.ons.gov.uk/peoplepopulationandc ommunity/birthsdeathsandmarriages/ageing/articles/livinglonger howourpopulationischangingandwhyitmatters/2019-03-15

3 Care Quality Commission. The state of health care and adult social care in England 2018/19. Newcastle-upon-Tyne: Care Quality Commission, 2019. https://www.cqc.org.uk/sites/default/files/ 20191015b_stateofcare1819_fullreport.pdf

4 Department of Health. Prime Minister's challenge on dementia 2020. London: Department of Health, 2015. https://assets.publishing. service.gov.uk/government/uploads/system/uploads/attachment_ data/file/414344/pm-dementia2020.pdf

5 Incisive Health. Care deserts: the impact of a dysfunctional market in adult social care provision. London: Incisive Health, 2019. https:// www.incisivehealth.com/wp-content/uploads/2019/05/caredeserts-age-uk-report.pdf

6 Age UK. Briefing: health and care of older people in England 2019. London: Age UK, 2019. https://www.ageuk.org.uk/globalassets/ age-uk/documents/reports-and-publications/reports-and-briefings/ health-wellbeing/age_uk_briefing_state_of_health_and_care_of older_people_july2019.pdf

7 Alzheimer's Society. A lonely future: 120,000 people with dementia living alone, set to double in the next 20 years. London: Alzheimer's Society, 2019. https://www.alzheimers.org.uk/news/2019-05-15/ lonely-future-120000-people-dementia-living-alone-set-doublenext-20-years

8 Cornwell EY, Waite LJ. Social disconnectedness, perceived isolation, and health among older adults. J Health Soc Behav 2009;50:31-48.

9 Holt-Lunstad J, Smith TB, Baker M, et al. Loneliness and social isolation as risk factors for mortality: a meta-analytic review. Perspect Psychol Sci 2015;10:227-37.

10 Brodaty H, Donkin M. Family caregivers of people with dementia. Dialogues Clin Neurosci 2009;11:217-28.

11 Alzheimer's Society. Worst hit: dementia during coronavirus. London: Alzheimer's Society, 2020. https://www.alzheimers.org.uk/ sites/default/files/2020-09/Worst-hit-Dementia-during-coronavirusreport.pdf

12 Brooker D, Evans S, Evans S, et al. Evaluation of the implementation of the meeting centres support program in Italy, Poland, and the UK; exploration of the effects on people with dementia. Int J Geriatr Psychiatry 2018;33:883-92.

13 Evans S, Evans S, Brooker D, et al. The impact of the implementation of the Dutch combined meeting centres support programme for family caregivers of people with dementia in Italy, Poland and UK. Aging Ment Health 2020;24:280-290.

14 Lord K, Beresford-Dent J, Rapaport P, et al. Developing the new interventions for independence in dementia study (nidus) theoretical model for supporting people to live well with dementia at home for longer: a systematic review of theoretical models and randomised controlled trial evidence. Soc Psychiatry Psychiatr Epidemiol 2020;55:1-14.

15 McDermott O, Charlesworth G, Hogervorst E, et al. Psychosocial interventions for people with dementia: a synthesis of systematic reviews. Aging Ment Health 2019;23:393-403.

16 Van't Leven N, Prick A-EJC, Groenewoud JG, et al. Dyadic interventions for community-dwelling people with dementia and their family caregivers: a systematic review. Int Psychogeriatr 2013;25:1581-603.

17 Dröes R-M, van der Roest HG, van Mierlo L, et al. Memory problems in dementia: adaptation and coping strategies and psychosocial treatments. Expert Rev Neurother 2011;11:1769-82.

18 Dröes R-M, Meiland F, Schmitz M, et al. Effect of combined support for people with dementia and carers versus regular day care on behaviour and mood of persons with dementia: results from a multi-centre implementation study. Int J Geriatr Psychiatry 2004;19:673-84.

19 Dröes R-M, Meiland FJM, Schmitz MJ, et al. Effect of the meeting centres support program on informal carers of people with dementia: results from a multi-centre study. Aging Ment Health 2006;10:112-24.

20 Wittenberg R, Hu B, Barraza-Araiza L, et al. Projections of older people with dementia and costs of dementia care in the United Kingdom, 2019-2040 (CPEC working paper 50). London: LSE, 2019. https://www.alzheimers.org.uk/sites/default/files/2019-11/cpec_ report_november_2019.pdf

21 Dröes R-M, Breebaart E, Meiland FJM, et al. Effect of meeting centres support program on feelings of competence of family carers and delay of institutionalization of people with dementia. Aging Ment Health 2004;8:201-11.

22 Dröes RM, Meiland FJM, Schmitz M, et al. Effect of combined support for people with dementia and carers versus regular day care on behaviour and mood of persons with dementia: results 
from a multicentre implementation study. Int $J$ Geriatr Psychiatry 2004:19:1-12.

23 Booth A, Clarke M, Ghersi D, et al. An international registry of systematic-review protocols. Lancet 2011;377:108-9.

24 Morton T, Atkinson T, Brooker D, et al. Sustainability of communitybased interventions for people affected by dementia: a protocol for the SCI-Dem realist review. BMJ Open 2019;9:e032109.

25 Pawson R. Evidence-based policy: a realist perspective. London: Sage Publications, 2006.

26 Pawson R, Greenhalgh T, Harvey G, et al. Realist review--a new method of systematic review designed for complex policy interventions. J Health Serv Res Policy 2005;10(Suppl 1):21-34

27 Jagosh J, Macaulay AC, Pluye P, et al. Uncovering the benefits of participatory research: implications of a realist review for health research and practice. Milbank Q 2012;90:311-46.

28 Astbury B, Leeuw F. Unpacking black boxes: mechanisms and theory building in evaluation. Am J Eval 2010;31:363-81.

29 Wong G, Greenhalgh T, Westhorp G, et al. Development of methodological guidance, publication standards and training materials for realist and meta-narrative reviews: the RAMESES (Realist And Meta-narrative Evidence Syntheses - Evolving Standards) project. Health Serv Deliv Res 2014;2:1-252.

30 DEEP. DEEP: the UK network of dementia voices website, 2020. Available: http://dementiavoices.org.uk

31 Greenhalgh T, Peacock R. Effectiveness and efficiency of search methods in systematic reviews of complex evidence: audit of primary sources. BMJ 2005;331:1064.

32 Booth A, Harris J, Croot E, et al. Towards a methodology for cluster searching to provide conceptual and contextual "richness" for systematic reviews of complex interventions: case study (CLUSTER). BMC Med Res Methodol 2013;13:118.

33 Pawson R, Greenhalgh T, Harvey G. Realist synthesis - an introduction. ESRC working paper series. London: ESRC, 2004.

34 Wong G. Data gathering in realist reviews: Looking for needles in haystacks. In: Emmel N, Greenhalgh J, Manzano A, eds. Doing realist research. London: Sage Publications, 2018: 131-45.

35 Pawson R. Digging for nuggets: How 'bad' research can yield 'good' evidence. Int J Soc Res Methodol 2006;9:127-42.

36 Powell M, Osborne SP, enterprises S. Marketing, and sustainable public service provision. International Review of Administrative Sciences 2020;86:62-79.

37 Powell M, Gillett A, Doherty B. Sustainability in social enterprise: hybrid organizing in public services. Public Management Review 2019;21:159-86.

38 Oyebode JR, Parveen S. Psychosocial interventions for people with dementia: an overview and commentary on recent developments. Dementia 2019;18:8-35.

39 Barbarino P, Lynch C, Bliss A. From plan to impact III: maintaining dementia as a priority in unprecedented times. London: Alzheimer's Disease International, 2020. https://www.alzint.org/u/from-plan-toimpact-2020.pdf

40 Canevelli M, Valletta M, Toccaceli Blasi M, et al. Facing dementia during the COVID-19 outbreak. J Am Geriatr Soc 2020;68:1673-6.

41 Actifcare. Best practice recommendations from the Actifcare study: access to community care services for home-dwelling people with dementia and their carers. Bangor: Dementia Services Development Centre Wales, 2017. http://dsdc.bangor.ac.uk/documents/Shortver sionBestPracticeRecommendationwithoutsupportingfindings_000. pdf

42 Daykin N, Julier G, Tomlinson A. Review of the grey literature: music, singing and wellbeing. London: What Works Wellbeing 2016. https://whatworkswellbeing.files.wordpress.com/2016/11/ grey-literature-review-music-singing-wellbeing-nov2016.pdf

43 Hochgraeber I, von Kutzleben M, Bartholomeyczik S, et al. Lowthreshold support services for people with dementia within the scope of respite care in Germany - A qualitative study on different stakeholders' perspective. Dementia 2017;16:576-90.

44 McDonald A, Heath B. Developing services for people with dementia. Work Older People 2009;13:18-21.

45 Strandenæs MG, Lund A, Rokstad AMM. Experiences of attending day care services designed for people with dementia - a qualitative study with individual interviews. Aging Ment Health 2018;22:764-72.

46 Van Mierlo LD, Chattat R, Evans S, et al. Facilitators and barriers to adaptive implementation of the meeting centers support program (MCSP) in three European countries; the process evaluation within the MEETINGDEM study. Int Psychogeriatr 2018;30:527-37.

47 Brooker D, Evans SB, Evans SC. Meeting centres support programme UK: overview, evidence and getting started.Worcester: association for dementia studies, University of worcester, 2017. Available: https://www.worcester.ac.uk/documents/Meeting-
Centres-Support-Progamme-Overview-evidence-and-gettingstarted-Conference-booklet.pdf

48 Glover C. Running self-help groups in sheltered and extra care accommodation for people who live with dementia. London: Mental Health Foundation, 2014. https://www.mentalhealth.org.uk/sites/ default/files/dementia-self-help-guide.pdf

49 Reichet M, Wolter V. Sport for people with dementia - implementing physical activity programs (PAP) for people with dementia: results from a German study (conference poster). Dortmund: TU Dortmund University, 2017.

50 Reichet M, Wolter V. Implementing physical ACTIVITIY programs for people with dementia: results from a German study. Innov Aging 2017;1:340.

51 The Me Myself and I Club. The me, Myself and I Club, Briton ferry: a case study in warm humanity and meaningful co-production. Neath Port Talbot: the me Myself and I Club, 2018. Available: https://info. copronet.wales/me-myself-and-i-club-briton-ferry/

52 Older People's Commissioner for Wales. Rethinking respite for people affected by dementia. Cardiff: Older People's Commissioner for Wales, 2018. http://www.olderpeoplewales.com/en/Reviews/ respite.aspx

53 Bould E, McFayden S, Thomas C. Dementia-friendly sport and physical activity guide. London: Alzheimer's Society, 2019. https://www.alzheimers.org.uk/get-involved/dementia-friendlycommunities/organisations/dementia-friendly-sports

54 Green G, Lakey L. Building dementia-friendly communities: a priority for everyone. London: Alzheimer's Society, 2013. https://actonalz. org/sites/default/files/documents/Dementia_friendly_communities_ full report.pdf

55 Marshall J, Jackson L. Encouraging and supporting the growth of "dementia proactive communities". Ipswich: Sue Ryder/The Debenham Project, 2015. http://www.the-debenham-project.org.uk/ downloads/conference/Supplementary\%20contributions/Lynden\% 20Jackson\%20\&\%20Jo\%20Marshall/Lynden\%20Jackson\%20\&\% 20\%20Jo\%20Marshall\%20-\%20Supplementary\%20Contribution. pdf

56 Clarke CL, Keyes SE, Wilkinson H, et al. Organisational space for partnership and sustainability: lessons from the implementation of the National dementia strategy for England. Health Soc Care Community 2014;22:634-45.

57 Health Innovation Network South London. Case study: dulwich helpline and southwark churches care (DH\&SCC) - the dementia project, Southwark, South London. London: Health Innovation Network South London, 2015. http://www.hin-southlondon.org/ system/resources/resources/000/000/083/original/Case_Study_ The_Healthy_Living_Club.pdf?1426083299

58 La Rue A, Felten K, Turkstra L. Intervention of multi-modal activities for older adults with dementia translation to rural communities. Am J Alzheimers Dis Other Demen 2015;30:468-77.

59 Mason T, Slack G. The Debenham project: research into the dementia/memory loss journey for cared-for and carer, 201213. Norwich: Norfolk \& Suffolk Dementia Alliance, 2013. http:// www.the-debenham-project.org.uk/downloads/articles/2014/ DebProjResearch_Final_Report_311013.pdf

60 Meiland FJM, Dröes RM, De Lange J, et al. Development of a theoretical model for tracing facilitators and barriers in adaptive implementation of innovative practices in dementia care. Arch Gerontol Geriatr Suppl 2004;38:279-90.

61 Research S. Public perceptions and experiences of communitybased end of life care initiatives: a qualitative research report. London: Public Health England, 2016. https://assets.publishing. service.gov.uk/government/uploads/system/uploads/attachment data/file/569711/Public_Perceptions_of_Community_Based_End_ of_Life_Care_Initiatives_Resea.pdf

62 Cahill S, Pierce M, Bobersky A. An evaluation report on flexible respite options of the living well with dementia project in Stillorgan and Blackrock. Dublin: Trinity College, 2014. https://www. researchgate.net/publication/331257213_An_Evaluation_Report on_Flexible_Respite_Options_of_the_Living_Well_with_Dementia Project in Stillorgan and Blackrock

63 Carone L, Tischler V, Dening T. Football and dementia: a qualitative investigation of a community based sports group for men with early onset dementia. Dementia 2016;15:1358-76.

64 Gajardo J, Aravena JM, Budinich M, et al. The Kintun program for families with dementia: from novel experiment to national policy (innovative practice). Dementia 2020;19:488-95.

65 Grinberg A, Lagunoff J, Phillips D. Multidisciplinary design and implementation of a day program specialized for the frontotemporal dementias. Am J Alzheimers Dis Other Demen 2008;22:499-506. 
66 Meiland FJM, Dröes R-M, de Lange J, et al. Facilitators and barriers in the implementation of the meeting centres model for people with dementia and their carers. Health Policy 2005;71:243-53.

67 Rio R. A community-based music therapy support group for people with alzheimer's disease and their caregivers: a sustainable partnership model. Front Med 2018;5:293.

68 Gottleib-Tanaka D. Creative expression, dementia and the therapeutic environment (PhD thesis). Vancouver: University of British Columbia, 2006. https://open.library.ubc.ca/clRcle/ collections/ubctheses/831/items/1.0076821

69 Mapes N, Milton S, Nicholls V. Is it nice outside? consulting people living with dementia and their carers about engaging with the natural environment. natural England commissioned reports, number 211. Natural England: York, 2016. http://publications.naturalengland.org. uk/publication/5910641209507840

70 Brataas HV, Bjugan $\mathrm{H}$, Wille $\mathrm{T}$, et al. Experiences of day care and collaboration among people with mild dementia. J Clin Nurs 2010;19:2839-48.

71 Casey J. Early onset dementia: getting out and about. Journal of Dementia Care 2004;12:12-13.

72 Oliver-Watkins F, Kendall N, Sow MT. Grow: Report from a two-year Social and Therapeutic Horticultural (STH) programme delivering table-top gardening courses to adults in the community aged 50 and over. Reading: Thrive, 2016.

73 Williams B, Roberts P. Friends in passing: social interaction at an adult day care center. Int J Aging Hum Dev 1995;41:63-78.

74 Alzheimer's Australia. The benefits of physical activity and exercise for people living with dementia (Dicussion paper 11. Sydney: Alzheimer's Australia, 2014. https://www.dementia.org.au/sites/ default/files/NSW/documents/AANSW DiscussionPaper11.pdf

75 Hayes R, Williamson M. Men's sheds: exploring the evidence for best practice. Melbourne: La Trobe University, 2007. https://www. researchgate.net/publication/259313489

76 Milligan C, Payne S, Bingley A, et al. Place and wellbeing: shedding light on activity interventions for older men. Ageing Soc 2013;35:124-49.

77 Tuppen J. The benefits of groups that provide cognitive stimulation for people with dementia. Nurs Older People 2012;24:20-4.

78 Mental Health Foundation. An evaluation of the standing together project. London: Mental Health Foundation, 2018. https://www. mentalhealth.org.uk/sites/default/files/standing-together-evaluationWEB.pdf

79 Thrive. Growing4life - a thrive community gardening project: a practical guide to setting up a community gardening project for people affected by mental ill health. Reading: Thrive, 2012. https:// www.lumi.org.uk/assets/resources-toolkits/event-and-projects/ G4L-Resource-Book.pdf

80 Tuppen J, Burton-Jones J. Cogs clubs: a helpful activity in early dementia. Journal of Dementia Care 2015;23:20-1.

81 Dean J, Silversides K, Crampton J. Evaluation of the Bradford dementia friendly communities programme. Jospeh Rowntree Foundation: York, 2015. https://www.jrf.org.uk/report/evaluationbradford-dementia-friendly-communities-programme

82 Dean J, Silversides K, Crampton J. Evaluation of the York dementia friendly communities programme. York: Jospeh Rowntree Foundation, 2015. https://www.jrf.org.uk/report/evaluation-yorkdementia-friendly-communities-programme

83 Noimuenwai P. Effectiveness of adult day care programs on health outcomes of Thai family caregivers of persons with dementia (PHD thesis). Kansas: University of Kansas, 2012. https://kuscholarworks. ku.edu/bitstream/handle/1808/11440/Noimuenwai_ku_0099D_ 12475_DATA_1.pdf?sequence=1\&isAllowed $=y$
84 van Haeften-van Dijk AM, Meiland FJM, van Mierlo LD, et al. Transforming nursing home-based day care for people with dementia into socially integrated community day care: process analysis of the transition of six day care centres. Int J Nurs Stud 2015:52:1310-22.

85 Health Innovation Network South London. Peer support for people with dementia resource pack. London: Health Innovation Network South London, 2015. https://dementiapartnerships.com/resource/ dementia-peer-support-resource-pack/

86 Hikichi H, Kondo K, Takeda T, et al. Social interaction and cognitive decline: results of a 7 -year community intervention. Alzheimers Dement 2017;3:23-32.

87 Hochgraeber I, Bartholomeyczik S, Holle B. Low-threshold support for families with dementia in Germany. BMC Res Notes 2012;5:317.

88 La Rue A, Felten K, Duschene K, et al. Language-enriched exercise plus socialization for older adults with dementia: translation to rural communities. Semin Speech Lang 2013;34:170-84.

89 Lockwood S. The Debenham project: a case study of a unique community-led and owned project dedicated to the support of carers of those that have symptoms of dementia and those they care for. Harrogate: Community Catalysts CIC, 2012. http:// www.the-debenham-project.org.uk/downloads/articles/2012/ 121106report.pdf

90 Health Innovation Network South London. Case study: the healthy living Club (HLC) - a self-directed, dementia-centred community group in Stockwell, London. London: Health Innovation Network South London, 2015. http://www.hin-southlondon.org/system/ resources/resources/000/000/084/original/Case Study The Dulwich Helpline and Southwark Churches.pdf?1426083406

91 Mangiaracina F, Chattat R, Farina E, et al. Not re-inventing the wheel: the adaptive implementation of the meeting centres support programme in four European countries. Aging Ment Health 2017;21:40-8.

92 Jackson L. The Debenham project: project Blog and catch-up (August 2017). Debenham, Suffolk: The Debenham Project, 2017. http://www.the-debenham-project.org.uk/downloads/newsletters/ blogs/1708.pdf

93 McAiney CA, Hillier LM, Stolee P. 'Throwing a lifeline': The role of First Link ${ }^{\mathrm{TM}}$ in enhancing support for individuals with dementia and their caregivers. Neurodegener Dis Manag 2012;2:623-38.

94 Moore KD. Observed affect in a dementia day center: does the physical setting matter? Alzheimers Care Q 2002;3:67-73.

95 Arthur A, Buckner S, Buswell M. DEMCOM: National evaluation of dementia friendly communities (Executive Summary). Cambridge: Applied Research Collaboration (ARC) East of England, 2020.

96 Kelsey SG, Laditka SB. Evaluating best practices for social model programs for adults with Alzheimer's disease in South Carolina. Home Health Care Serv Q 2006;24:21-46.

97 Arkin SM, Morrow-Howell N. Elder rehab: a student-supervised exercise program for Alzheimer's patients. Gerontologist 1999;39:729-35.

98 LeBlanc LA. Integrating behavioral psychology services into adult day programming for individuals with dementia. Behav Modif 2010;34:443-58.

99 NCVO. How to fundraise in tough times. London: NCVO, 2019. https://knowhow.ncvo.org.uk/how-to/how-to-fundraise-in-toughtimes

100 Wimo A, Wallin JO, Lundgren K, et al. Impact of day care on dementia patients--costs, well-being and relatives' views. Fam Pract 1990;7:279-87.

101 Shnall A, Agate A, Grinberg A, et al. Development of supportive services for frontotemporal dementias through community engagement. Int Rev Psychiatry 2013;25:246-52. 
Supplementary file 1: Initial programme theory diagrams and coding themes

Key to colour coding:

- How it's run

- Network and marketing

- Barriers (psychological and practical)

- Resources and practicalities 


\section{Barriers and facilitators to engagement}

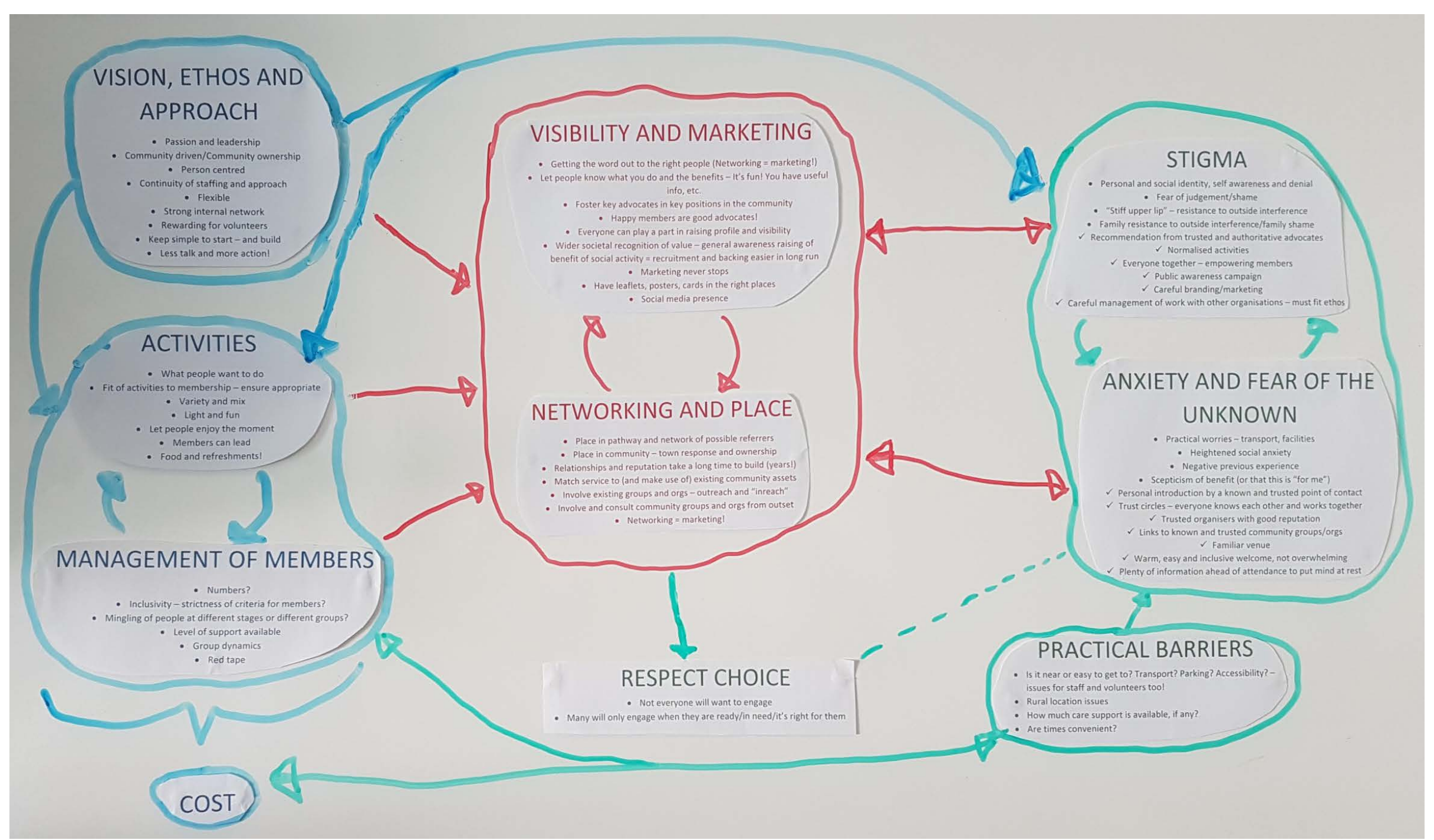




\section{Barriers and facilitators to sustainability}

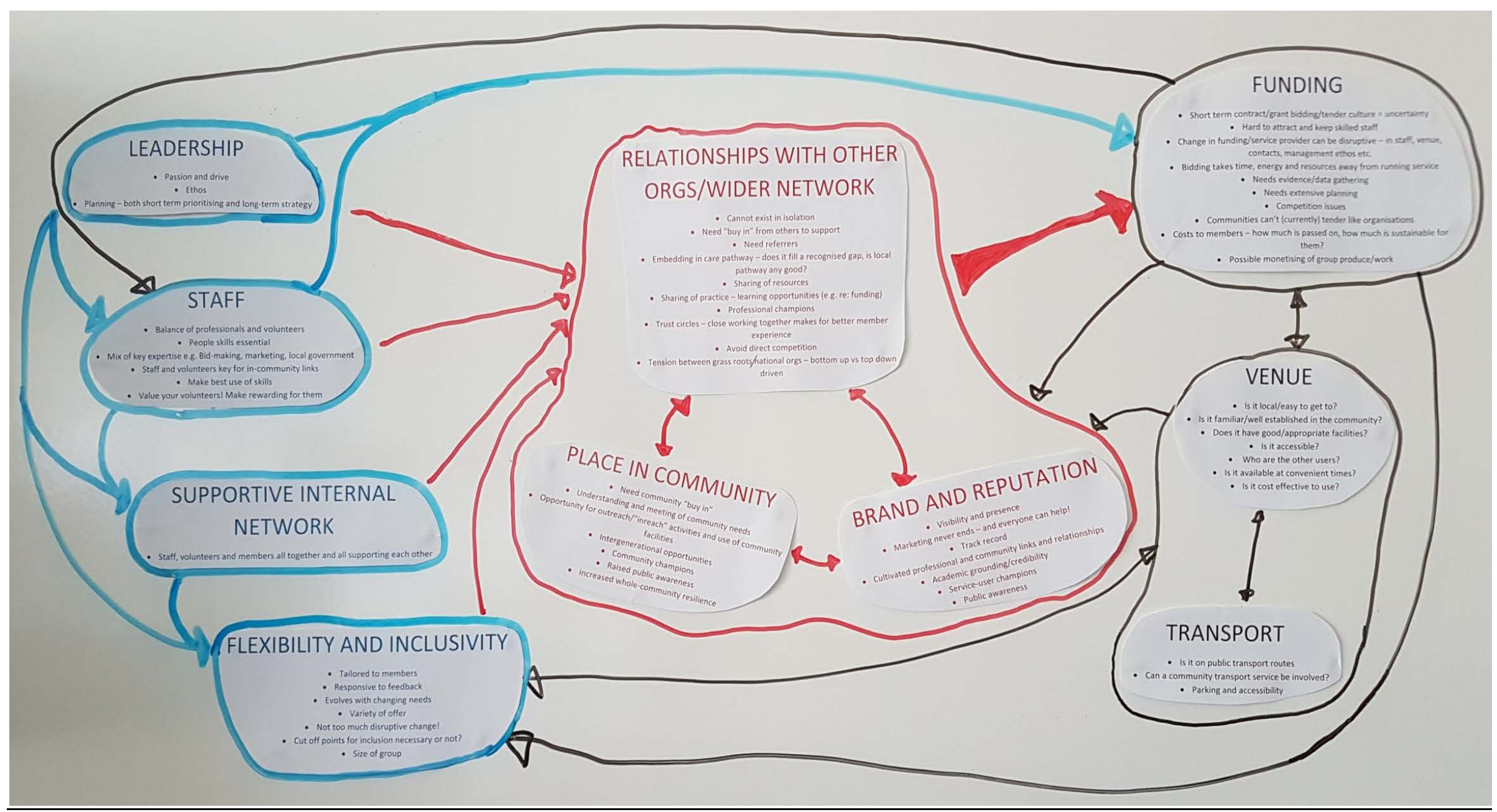




\section{Top-level "parent" coding categories in NVivo analysis of the data}

\begin{tabular}{|c|c|c|c|c|c|}
\hline Name & $\mathrm{cos}$ & Files & References & \#: & \multirow{8}{*}{ "How it's run" } \\
\hline Leadership & & 54 & 226 & 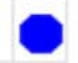 & \\
\hline Management of members (inc flexibility and inclusivity) & & 66 & 219 & & \\
\hline Staff and volunteer issues & & 71 & 196 & & \\
\hline Activities & & 94 & 577 & & \\
\hline Ethos and approach & & 92 & 556 & & \\
\hline Stability and reliabiltiy of provision & & 14 & 23 & & \\
\hline Anxiety and fear of unknown & & 65 & 321 & $\mathrm{C}$ & \\
\hline Transport and geography & & 39 & 87 & O & \multirow{4}{*}{$\begin{array}{c}\text { Barriers to } \\
\text { engagement }\end{array}$} \\
\hline Venue issues & & 60 & 203 & O & \\
\hline Attendee characteristics & & 62 & 216 & O & \\
\hline Difficulty becoming a member & & 23 & 50 & O & \\
\hline Visibility and marketing & & 76 & 365 & O & \multirow{3}{*}{$\begin{array}{l}\text { Networking } \\
\text { \& marketing }\end{array}$} \\
\hline Place in the community & & 67 & 295 & 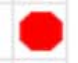 & \\
\hline Relationships with other organisations & & 71 & 567 & & \\
\hline Funding issues & & 64 & 327 & C) & Money \& \\
\hline Cost effectiveness issues & & 35 & 68 & $(t)$ & resources \\
\hline
\end{tabular}




\section{Supplementary file 2: Search strategy}

\section{Databases:}

EBSCOhost: Academic Search Complete, CINAHL, MEDLINE, PsychINFO

Other health and social care databases: AMED,Embase, PubMed, Social Care Online

Interdisciplinary databases: ProQuest, Scopus

Systematic reviews: Cochrane Library, Campbell Collaboration

Other/general: Google Scholar

Limiters: Published 1990 to present

\begin{tabular}{|c|c|}
\hline Key terms & String of related terms \\
\hline Dementia & Dementia \\
\hline Community & Commun* OR Local* OR Social* \\
\hline Intervention & $\begin{array}{l}\text { Intervention OR Program* OR Project OR } \\
\text { Initiative OR Scheme OR Service OR Activit* OR } \\
\text { Group OR Club OR Network OR Meeting OR } \\
\text { Therapy }\end{array}$ \\
\hline Sustainability & $\begin{array}{l}\text { Sustain* OR Maint* OR Manag* OR Facilitat* } \\
\text { OR Barrier* }\end{array}$ \\
\hline Implementation and Engagement & Implement* OR Recruit* OR Engag* \\
\hline
\end{tabular}

Dementia AND (Commun* OR Local* OR Social*) AND (Intervention OR Program* OR Project OR Initiative OR Scheme OR Service OR Activit* OR Group OR Club OR Network OR Meeting OR Therapy) AND (Sustain* OR Maint* OR Manag* OR Facilitat* OR Barrier*)AND (Implement* OR Recruit* OR Engag*)

NOTES:

Search terms were kept uniform across all databases and searching was carried out by looking for the occurrence of these terms within the title, abstract and key words of documents in each database. If a database did not allow for this, the strategy was altered slightly to the closest option (e.g. in ProQuest this was searching everywhere in a document except full text; in PubMed this was by carrying out three separate searches by title content, by abstract content and key word content, then combining the results). 


\section{Supplementary file 3: Inclusion and assessment criteria}

\section{Inclusion and exclusion criteria for formal search:}

Inclusion criteria
Types of intervention for inclusion should:

- Target people with mild to moderate dementia (whether exclusively or among others without dementia, but either way there is dementia-specific support)

- Serve people living in the community, whether in their own homes or in extracare housing

- Are voluntary attendance (i.e. members have chosen to attend, not been told they must as part of treatment or respite care)

- Are social and place-based (bringing people together physically) in a community setting (open to members of the public to attend)

- Are designed as an intervention with meaningful activity aiming to improve quality of life for people with dementia and family carers, or to help them manage or lessen the challenging effects dementia

- Meet at regular, pre-fixed times, at least weekly and for a substantial amount of time (i.e. a morning or afternoon)

- Meet continuously, on an ongoing basis, or aim to do so

\section{Exclusion criteria}

Interventions will be excluded if they:

- Are only for those with severe dementia

- Do not target, and have no plan to cater for, people with dementia

- Are only for care home residents, hospital patients or those in a closed institutional setting

- Are an online or at-a-distance networking scheme that does not involve meeting physically

- Only involve individual participants alone (e.g. occupational therapy, counselling or medical)

- Are only functional meetings solely for the purpose of administering medical treatment or carry out case management

- Are focussed mainly upon respite for carers or nursing care only (i.e. not focussed upon social, meaningful and quality-of-life-raising activities for those attending)

- Only take place monthly; or for a very short duration (e.g. one hour); or intermittently with no specified or timetabled meetings

- $\quad$ Are fixed-term courses with a time/goal/session limit (e.g. an 8 week course)

\section{Relevance and rigour assessment guidance:}

\section{Relevance}

An article should comply with the

inclusion/exclusion criteria in the first instance, except where agreed by the team for inclusion for a specific reason e.g. containing data that is broadly transferable and of use to the programme theory.

\section{Rigour}

This is an assessment of the likely validity and reliability only of the relevant data contained in an article, not an assessment of the rigour of a study or intervention programme as a whole. Useful questions might include: Is this data likely to be biased? Is it dealt with critically? Is it from a real-world example or theoretical speculation? Was the data gathered in some depth over time or in a quick "snapshot"? Is it safe to generalise from this data? 


\begin{tabular}{|l|l|}
\hline $\begin{array}{l}\text { Reasons for rating must be recorded. For } \\
\text { example: }\end{array}$ & $\begin{array}{l}\text { Reasons for rating must be recorded. For } \\
\text { example: }\end{array}$ \\
\hline $\begin{array}{l}\text { A low rating might mean the article only } \\
\text { contains a few relevant lines, with the bulk of } \\
\text { the text focused on other, non-relevant matters }\end{array}$ & $\begin{array}{l}\text { A low rating might mean data appears } \\
\text { uncritically treated and at a high risk of bias (e.g. } \\
\text { from a promotional article for a service) or } \\
\text { simply descriptive and superficial in its reporting } \\
\text { of basic facts from an intervention programme } \\
\text { (e.g. from a short news article) }\end{array}$ \\
$\begin{array}{l}\text { A medium rating might mean an article has a lot } \\
\text { of detail on one relevant issue (e.g. engaging } \\
\text { people and keeping them engaged) which is } \\
\text { pertinent to sustainability, but otherwise little on } \\
\text { other important factors }\end{array}$ & $\begin{array}{l}\text { A medium rating might mean data appears with } \\
\text { some attempt at critical evaluation and is from a } \\
\text { real-world example, but is limited in scope and } \\
\text { generalisability, or in depth and detail }\end{array}$ \\
$\begin{array}{l}\text { A high rating will mean an article has a direct } \\
\text { focus on keeping an intervention sustainable } \\
\text { long term, with a good level of detail }\end{array}$ & $\begin{array}{l}\text { A high rating might mean data is of good depth } \\
\text { and detail and is from a critical evaluation of at } \\
\text { least one real world example, gathered over a } \\
\text { sustained period using range of robust measures } \\
\text { and an appropriate sample of participants }\end{array}$ \\
\end{tabular}




\section{Supplementary file 4: Full lists of included articles}

\begin{tabular}{|c|c|c|c|c|c|c|c|}
\hline Author(s) & Year & Article title & $\begin{array}{l}\text { Type of } \\
\text { intervention }\end{array}$ & Country of origin & $\begin{array}{l}\text { Type of } \\
\text { article/study }\end{array}$ & Publication & $\begin{array}{l}\text { Reference } \\
\text { list No. }\end{array}$ \\
\hline Actifcare & 2017 & $\begin{array}{l}\text { Best practice } \\
\text { recommendations from the } \\
\text { Actifcare study: Access to } \\
\text { community care services for } \\
\text { home-dwelling people with } \\
\text { dementia and their carers }\end{array}$ & $\begin{array}{l}\text { community care } \\
\text { services in } \\
\text { general }\end{array}$ & $\begin{array}{l}\text { Netherlands, } \\
\text { Germany, Sweden, } \\
\text { UK, Norway, Ireland, } \\
\text { Portugal, Italy }\end{array}$ & $\begin{array}{l}\text { Recommendations } \\
\text { report }\end{array}$ & www.actifcare.eu & 36 \\
\hline $\begin{array}{l}\text { Alzheimer's } \\
\text { Australia }\end{array}$ & 2014 & $\begin{array}{l}\text { The benefits of physical activity } \\
\text { and exercise for people living } \\
\text { with dementia (Dicussion } \\
\text { paper 11) }\end{array}$ & Exercise activities & Australia & Report & $\begin{array}{l}\text { Alzheimer's } \\
\text { Australia }\end{array}$ & 69 \\
\hline Arkin & 1999 & $\begin{array}{l}\text { Elder rehab: A student- } \\
\text { supervised exercise program } \\
\text { for Alzheimer's patients }\end{array}$ & $\begin{array}{l}\text { Weekly exercise } \\
\text { programme } \\
\text { pairing elders and } \\
\text { student helpers at } \\
\text { a college gym } \\
\text { (caregivers also } \\
\text { involved) }\end{array}$ & US & $\begin{array}{l}\text { Journal paper - } \\
\text { programme pilot }\end{array}$ & The Gerontologist & 92 \\
\hline $\begin{array}{l}\text { Arthur, Buckner, } \\
\text { Buswell, Darlington, } \\
\text { Killett, Lafortune, } \\
\text { Mathie, Mayrhofer, } \\
\text { Skedgel, Woodward } \\
\text { \& Goodman }\end{array}$ & 2020 & $\begin{array}{l}\text { DEMCOM: National Evaluation } \\
\text { of Dementia Friendly } \\
\text { Communities (Executive } \\
\text { Summary) }\end{array}$ & $\begin{array}{l}\text { Dementia } \\
\text { Friendly } \\
\text { Communities - } \\
\text { various social and } \\
\text { leisure activities }\end{array}$ & UK & Evaluation report & $\begin{array}{l}\text { Applied Research } \\
\text { Collaboration (ARC) } \\
\text { East of England }\end{array}$ & 90 \\
\hline
\end{tabular}




\begin{tabular}{|c|c|c|c|c|c|c|c|}
\hline $\begin{array}{l}\text { Bould, McFadyen \& } \\
\text { Thomas }\end{array}$ & 2019 & $\begin{array}{l}\text { Dementia-friendly sport and } \\
\text { physical activity guide }\end{array}$ & $\begin{array}{l}\text { Sport and } \\
\text { excercise } \\
\text { initiatives }\end{array}$ & UK & $\begin{array}{l}\text { Information } \\
\text { booklet }\end{array}$ & Alzheimer's Society & 48 \\
\hline $\begin{array}{l}\text { Brataas, Bjugan, } \\
\text { Wille \& Hellzen }\end{array}$ & 2010 & $\begin{array}{l}\text { Experiences of day care and } \\
\text { collaboration among people } \\
\text { with mild dementia }\end{array}$ & Day care & Norway & $\begin{array}{l}\text { Journal paper - qual } \\
\text { study of a trial } \\
\text { programme }\end{array}$ & $\begin{array}{l}\text { Journal of Clinical } \\
\text { Nursing }\end{array}$ & 65 \\
\hline $\begin{array}{l}\text { Brooker, Evans, } \\
\text { Evans, Watts \& } \\
\text { Droes }\end{array}$ & 2017 & $\begin{array}{l}\text { Meeting Centres Support } \\
\text { Programme UK: Overview, } \\
\text { evidence and } \\
\text { getting started }\end{array}$ & Meeting Centres & $\begin{array}{l}\text { Netherlands, Italy, } \\
\text { Poland, UK }\end{array}$ & $\begin{array}{l}\text { Information/guide } \\
\text { booklet }\end{array}$ & $\begin{array}{l}\text { Association for } \\
\text { Dementia Studies } \\
\text { (University of } \\
\text { Worcester) }\end{array}$ & 42 \\
\hline $\begin{array}{l}\text { Cahill, Pierce \& } \\
\text { Bobersky }\end{array}$ & 2014 & $\begin{array}{l}\text { An evaluation report on } \\
\text { flexible respite options of the } \\
\text { Living Well With Dementia } \\
\text { project in Stillorgan and } \\
\text { Blackrock }\end{array}$ & Day care/respite & Ireland & Evaluation report & $\begin{array}{l}\text { Trinity College } \\
\text { Dublin }\end{array}$ & 57 \\
\hline
\end{tabular}




\begin{tabular}{|c|c|c|c|c|c|c|c|}
\hline $\begin{array}{l}\text { Carone, Tischler \& } \\
\text { Dening }\end{array}$ & 2016 & $\begin{array}{l}\text { Football and dementia: A } \\
\text { qualitative investigation of a } \\
\text { community based sports group } \\
\text { for men with early onset } \\
\text { dementia }\end{array}$ & $\begin{array}{l}\text { Sport and } \\
\text { excercise group }\end{array}$ & UK & $\begin{array}{l}\text { Journal paper- } \\
\text { qualitative study }\end{array}$ & Dementia & \begin{tabular}{|l|l|}
58 & \\
\end{tabular} \\
\hline Casey & 2004 & $\begin{array}{l}\text { Early onset dementia: Getting } \\
\text { out and about }\end{array}$ & $\begin{array}{l}\text { Small "out and } \\
\text { about" social } \\
\text { group }\end{array}$ & UK & $\begin{array}{l}\text { Specialist news } \\
\text { article }\end{array}$ & $\begin{array}{l}\text { Journal of } \\
\text { Dementia Care }\end{array}$ & 66 \\
\hline $\begin{array}{l}\text { Clarke, Keyes, } \\
\text { Wilkinson, Alexjuk, } \\
\text { Wilcockson, } \\
\text { Robinson, Corner \& } \\
\text { Cattan }\end{array}$ & 2014 & $\begin{array}{l}\text { Organisational space for } \\
\text { partnership and sustainability: } \\
\text { lessons from the } \\
\text { implementation of the } \\
\text { National Dementia Strategy for } \\
\text { England }\end{array}$ & $\begin{array}{l}\text { Peer support } \\
\text { networks }\end{array}$ & UK & $\begin{array}{l}\text { Journal paper - } \\
\text { stragtegy } \\
\text { evaluation }\end{array}$ & $\begin{array}{l}\text { Health \& Social } \\
\text { Care in the } \\
\text { Community }\end{array}$ & 51 \\
\hline $\begin{array}{l}\text { Daykin, Julier, } \\
\text { Tomlinson, Meads, } \\
\text { Mansfield, Payne, } \\
\text { Duffy, Lane, } \\
\text { D'Innocenzo, } \\
\text { Burnett, Kay, Dolan, } \\
\text { Testoni \& Victor }\end{array}$ & 2016 & $\begin{array}{l}\text { Review of the grey literature: } \\
\text { music, singing and wellbeing }\end{array}$ & $\begin{array}{l}\text { Singing and } \\
\text { musical activities }\end{array}$ & UK & Review/Report & $\begin{array}{l}\text { What Works } \\
\text { Wellbeing report }\end{array}$ & 37 \\
\hline
\end{tabular}




\begin{tabular}{|c|c|c|c|c|c|c|c|}
\hline $\begin{array}{l}\text { Dean, Silversides, } \\
\text { Crampton \& } \\
\text { Wrigley }\end{array}$ & 2015 & $\begin{array}{l}\text { Evaluation of the Bradford } \\
\text { Dementia Friendly } \\
\text { Communities Programme }\end{array}$ & $\begin{array}{l}\text { Activities and } \\
\text { groups in the } \\
\text { community }\end{array}$ & UK & Evaluation report & $\begin{array}{l}\text { Joseph Rowntree } \\
\text { Foundation report }\end{array}$ & 76 \\
\hline $\begin{array}{l}\text { Dean, Silversides, } \\
\text { Crampton \& } \\
\text { Wrigley }\end{array}$ & 2015 & $\begin{array}{l}\text { Evaluation of the York } \\
\text { Dementia Friendly } \\
\text { Communities Programme }\end{array}$ & $\begin{array}{l}\text { Activities and } \\
\text { groups in the } \\
\text { community }\end{array}$ & UK & Evaluation report & $\begin{array}{l}\text { Joseph Rowntree } \\
\text { Foundation report }\end{array}$ & 77 \\
\hline $\begin{array}{l}\text { Gajardo, Aravena, } \\
\text { Budinich, Larrain, } \\
\text { Fuentes \& Gitlin }\end{array}$ & 2017 & $\begin{array}{l}\text { The Kintun program for } \\
\text { families with dementia: From } \\
\text { novel experiment to national } \\
\text { policy (innovative practice) }\end{array}$ & $\begin{array}{l}\text { Day centre and } \\
\text { dementia } \\
\text { community hub }\end{array}$ & Chile & $\begin{array}{l}\text { Journal article - } \\
\text { program evaluation }\end{array}$ & Dementia & 59 \\
\hline Glover & 2014 & $\begin{array}{l}\text { Running self-help groups in } \\
\text { sheltered and extra care } \\
\text { accommodation for people } \\
\text { who live with dementia }\end{array}$ & $\begin{array}{l}\text { Self-help social } \\
\text { and activity } \\
\text { groups }\end{array}$ & UK & $\begin{array}{l}\text { Information/guide } \\
\text { booklet }\end{array}$ & $\begin{array}{l}\text { Mental Health } \\
\text { Foundation }\end{array}$ & 43 \\
\hline
\end{tabular}




\begin{tabular}{|c|c|c|c|c|c|c|c|}
\hline Gottlieb-Tanaka & 2006 & $\begin{array}{l}\text { Creative expression, dementia } \\
\text { and the therapeutic } \\
\text { environment }\end{array}$ & $\begin{array}{l}\text { Art/creative } \\
\text { activities in a day } \\
\text { centre } \\
\text { environment }\end{array}$ & Canada & Dissertation/Thesis & & 63 \\
\hline $\begin{array}{l}\text { Green \& Lakey } \\
\text { (Alzheimer's } \\
\text { Society) }\end{array}$ & 2013 & $\begin{array}{l}\text { Building dementia-friendly } \\
\text { communities: a priority for } \\
\text { everyone }\end{array}$ & $\begin{array}{l}\text { Dementia } \\
\text { Friendly } \\
\text { Communities - } \\
\text { various social and } \\
\text { leisure activities }\end{array}$ & UK & Report & Alzheimer's Society & 49 \\
\hline $\begin{array}{l}\text { Grinberg, Lagunoff, } \\
\text { Phillips, Stern, } \\
\text { Goodman \& Chow }\end{array}$ & 2007 & $\begin{array}{l}\text { Multidisciplinary design and } \\
\text { implementation of a day } \\
\text { program specialized for the } \\
\text { frontotemporal dementias }\end{array}$ & $\begin{array}{l}\text { Day program for } \\
\text { people with FTD }\end{array}$ & Canada & $\begin{array}{l}\text { Journal paper - } \\
\text { program evaluation }\end{array}$ & $\begin{array}{l}\text { American Journal of } \\
\text { Alzheimer's Disease } \\
\text { \& Other Dementias }\end{array}$ & 60 \\
\hline Hayes \& Williamson & 2007 & $\begin{array}{l}\text { Men's Sheds: Exploring the } \\
\text { Evidence for Best Practice }\end{array}$ & Men's Sheds & Australia & Evaluation report & $\begin{array}{l}\text { School of Public } \\
\text { Health, La Trobe } \\
\text { University }\end{array}$ & 70 \\
\hline
\end{tabular}




\begin{tabular}{|c|c|c|c|c|c|c|c|}
\hline $\begin{array}{l}\text { Health Innovation } \\
\text { Network South } \\
\text { London** (**see } \\
\text { also linked films } \\
\text { within document } \\
\text { plus } 2015 \text { HIN Case } \\
\text { Studies) }\end{array}$ & 2015 & $\begin{array}{l}\text { Peer Support for People with } \\
\text { Dementia Resource Pack }\end{array}$ & $\begin{array}{l}\text { A range of peer } \\
\text { support groups } \\
\text { and activities }\end{array}$ & UK & $\begin{array}{l}\text { Information/guide } \\
\text { booklet }\end{array}$ & $\begin{array}{l}\text { Health Innovation } \\
\text { Network South } \\
\text { London }\end{array}$ & 80 \\
\hline $\begin{array}{l}\text { Health Innovation } \\
\text { Network South } \\
\text { London }\end{array}$ & 2015 & $\begin{array}{l}\text { Case Study: Dulwich Helpline } \\
\text { and Southwark Churches Care } \\
\text { (DH\&SCC) - The Dementia } \\
\text { Project, Southwark, South } \\
\text { London. }\end{array}$ & $\begin{array}{l}\text { Peer support } \\
\text { project }\end{array}$ & UK & $\begin{array}{l}\text { Information/guide } \\
\text { booklet }\end{array}$ & $\begin{array}{l}\text { Health Innovation } \\
\text { Network South } \\
\text { London }\end{array}$ & 52 \\
\hline $\begin{array}{l}\text { Health Innovation } \\
\text { Network South } \\
\text { London }\end{array}$ & 2015 & $\begin{array}{l}\text { Case Study: The Healthy Living } \\
\text { Club (HLC) - A self-directed, } \\
\text { dementia-centred community } \\
\text { group in Stockwell, London }\end{array}$ & $\begin{array}{l}\text { Peer support } \\
\text { group }\end{array}$ & UK & $\begin{array}{l}\text { Information/guide } \\
\text { booklet }\end{array}$ & $\begin{array}{l}\text { Health Innovation } \\
\text { Network South } \\
\text { London }\end{array}$ & 85 \\
\hline $\begin{array}{l}\text { Hikichi, Kondo, } \\
\text { Takeda \& Kawachi }\end{array}$ & 2017 & $\begin{array}{l}\text { Social interaction and cognitive } \\
\text { decline: Results of a 7-year } \\
\text { community } \\
\text { intervention }\end{array}$ & $\begin{array}{l}\text { Community } \\
\text { centres for older } \\
\text { people }\end{array}$ & Japan & $\begin{array}{l}\text { Journal paper - } \\
\text { longitudinal study }\end{array}$ & $\begin{array}{l}\text { Alzheimer's \& } \\
\text { Dementia }\end{array}$ & 81 \\
\hline
\end{tabular}




\begin{tabular}{|c|c|c|c|c|c|c|c|}
\hline $\begin{array}{l}\text { Hochgraeber, } \\
\text { Bartholomeyczik \& } \\
\text { Holle** (**See also } \\
\text { Hochgraeber et al } \\
\text { 2017) }\end{array}$ & 2012 & $\begin{array}{l}\text { Low-threshold support for } \\
\text { families with dementia in } \\
\text { Germany }\end{array}$ & $\begin{array}{l}\text { "Low threshold" } \\
\text { support services } \\
\text { including social } \\
\text { care groups }\end{array}$ & Germany & $\begin{array}{l}\text { Journal paper- } \\
\text { survey protocol }\end{array}$ & $\begin{array}{l}\text { BMC Research } \\
\text { Notes }\end{array}$ & 82 \\
\hline $\begin{array}{l}\text { Hochgraeber, Von } \\
\text { Kutzleben, } \\
\text { Bartholomeyczik \& } \\
\text { Holle }\end{array}$ & 2017 & $\begin{array}{l}\text { Low-threshold support services } \\
\text { for people with dementia } \\
\text { within the scope of respite care } \\
\text { in Germany-A qualitative } \\
\text { study on different } \\
\text { stakeholders' perspective }\end{array}$ & $\begin{array}{l}\text { "Low threshold" } \\
\text { support services } \\
\text { including social } \\
\text { care groups }\end{array}$ & Germany & $\begin{array}{l}\text { Journal paper- } \\
\text { qualitative study }\end{array}$ & Dementia & 38 \\
\hline Jackson & 2017 & $\begin{array}{l}\text { The Debenham Project: Project } \\
\text { Blog and Catch-Up }\end{array}$ & $\begin{array}{l}\text { Range of local } \\
\text { support groups } \\
\text { and activities }\end{array}$ & UK & $\begin{array}{l}\text { Project blog } \\
\text { newsletter/report }\end{array}$ & Debenham Project & 87 \\
\hline Kelsey \& Laditka & 2005 & $\begin{array}{l}\text { Evaluating best practices for } \\
\text { social model programs for } \\
\text { adults with Alzheimer's disease } \\
\text { in South Carolina }\end{array}$ & $\begin{array}{l}\text { "Social model" } \\
\text { day care }\end{array}$ & US & $\begin{array}{l}\text { Journal paper - } \\
\text { review and survey } \\
\text { of best practice }\end{array}$ & $\begin{array}{l}\text { Home Health Care } \\
\text { Services Quarterly }\end{array}$ & 91 \\
\hline
\end{tabular}




\begin{tabular}{|c|c|c|c|c|c|c|c|}
\hline $\begin{array}{l}\text { La Rue, Felten, } \\
\text { Duschene, } \\
\text { MacFarlane, Price, } \\
\text { Zimmerman \& } \\
\text { Havez }\end{array}$ & 2013 & $\begin{array}{l}\text { Language-enriched exercise } \\
\text { plus socialization for older } \\
\text { adults with dementia: } \\
\text { Translation to rural } \\
\text { communities }\end{array}$ & $\begin{array}{l}\text { Language, } \\
\text { excercise and } \\
\text { socialisation } \\
\text { program }\end{array}$ & US & $\begin{array}{l}\text { Journal paper - trial } \\
\text { progam in rural } \\
\text { setting }\end{array}$ & $\begin{array}{l}\text { Seminars in Speech } \\
\text { and Language }\end{array}$ & 83 \\
\hline $\begin{array}{l}\text { La Rue, Felten \& } \\
\text { Turkstra }\end{array}$ & 2015 & $\begin{array}{l}\text { Intervention of Multi-Modal } \\
\text { Activities for Older Adults With } \\
\text { Dementia Translation to Rural } \\
\text { Communities }\end{array}$ & $\begin{array}{l}\text { Language, } \\
\text { excercise and } \\
\text { socialisation } \\
\text { program }\end{array}$ & US & $\begin{array}{l}\text { Journal paper - trial } \\
\text { progam in rural } \\
\text { setting }\end{array}$ & $\begin{array}{l}\text { American Journal of } \\
\text { Alzheimer's Disease } \\
\text { \& Other Dementias }\end{array}$ & 53 \\
\hline LeBlanc & 2010 & $\begin{array}{l}\text { Integrating behavioral } \\
\text { psychology services into adult } \\
\text { day programming for } \\
\text { individuals with dementia }\end{array}$ & $\begin{array}{l}\text { Day care (for } \\
\text { people with } \\
\text { dementia } \\
\text { exhibiting } \\
\text { challenging } \\
\text { behaviour) }\end{array}$ & US & $\begin{array}{l}\text { Journal paper - } \\
\text { program evaluation }\end{array}$ & $\begin{array}{l}\text { Behavior } \\
\text { Modification }\end{array}$ & \begin{tabular}{|l|}
93 \\
\end{tabular} \\
\hline Lockwood & 2012 & $\begin{array}{l}\text { The Debenham Project: A case } \\
\text { study of a unique community- } \\
\text { led and owned project } \\
\text { dedicated to the support of } \\
\text { carers of those that have } \\
\text { symptoms of dementia and } \\
\text { those they care for }\end{array}$ & $\begin{array}{l}\text { Range of local } \\
\text { support groups } \\
\text { and activities }\end{array}$ & UK & Case study report & $\begin{array}{l}\text { Community } \\
\text { Catalysts }\end{array}$ & 84 \\
\hline
\end{tabular}




\begin{tabular}{|c|c|c|c|c|c|c|c|}
\hline $\begin{array}{l}\text { Mangiaracina, } \\
\text { Chattat, Farina, } \\
\text { Saibene, } \\
\text { Gamberini, } \\
\text { Brooker, Evans, } \\
\text { Evans, Szcześniak, } \\
\text { Urbanska, } \\
\text { Rymaszewska, } \\
\text { Hendricks, Dröes \& } \\
\text { Meiland }\end{array}$ & 2017 & $\begin{array}{l}\text { Not re-inventing the wheel: the } \\
\text { adaptive implementation of } \\
\text { the meeting centres support } \\
\text { programme in four European } \\
\text { countries }\end{array}$ & Meeting Centres & $\begin{array}{l}\text { Netherlands, Italy, } \\
\text { Poland, UK }\end{array}$ & $\begin{array}{l}\text { Journal paper - } \\
\text { project evaluation }\end{array}$ & $\begin{array}{l}\text { Aging \& Mental } \\
\text { Health }\end{array}$ & 86 \\
\hline $\begin{array}{l}\text { Mapes, Milton, } \\
\text { Nicholls \& } \\
\text { Williamson (Natural } \\
\text { England) }\end{array}$ & 2016 & $\begin{array}{l}\text { Is it nice outside? Consulting } \\
\text { people living with dementia } \\
\text { and their carers about } \\
\text { engaging with the natural } \\
\text { environment }\end{array}$ & $\begin{array}{l}\text { Outdoor } \\
\text { activities }\end{array}$ & UK & Report & $\begin{array}{l}\text { Natural England } \\
\text { report }\end{array}$ & 64 \\
\hline Marshall \& Jackson & 2015 & $\begin{array}{l}\text { Encouraging and supporting } \\
\text { the growth of "dementia } \\
\text { proactive communities" }\end{array}$ & $\begin{array}{l}\text { Dementia } \\
\text { proactive } \\
\text { communities } \\
\text { (Range of local } \\
\text { support groups } \\
\text { and activities) }\end{array}$ & UK & Report & $\begin{array}{l}\text { Debenham Project } \\
\text { \& Sue Ryder }\end{array}$ & 50 \\
\hline Mason \& Slack & 2013 & $\begin{array}{l}\text { The Debenham Project: } \\
\text { Research into the } \\
\text { dementia/memory loss journey } \\
\text { for cared-for and carer, 2012- } \\
13\end{array}$ & $\begin{array}{l}\text { Range of local } \\
\text { support groups } \\
\text { and activities }\end{array}$ & UK & $\begin{array}{l}\text { Evaluation report - } \\
\text { survey }\end{array}$ & $\begin{array}{l}\text { Norfolk \& Suffolk } \\
\text { Dementia Alliance }\end{array}$ & 54 \\
\hline
\end{tabular}




\begin{tabular}{|c|c|c|c|c|c|c|c|}
\hline $\begin{array}{l}\text { McAiney, Hillier, } \\
\text { Stolee, Harvey \& } \\
\text { Michael }\end{array}$ & 2012 & $\begin{array}{l}\text { 'Throwing a lifeline': the role of } \\
\text { First Link in enhancing support } \\
\text { for } \\
\text { individuals with dementia and } \\
\text { their caregivers }\end{array}$ & $\begin{array}{l}\text { Information on } \\
\text { and links between } \\
\text { support services } \\
\text { (including groups } \\
\text { and activities) }\end{array}$ & Canada & $\begin{array}{l}\text { Journal paper- } \\
\text { evaluation }\end{array}$ & $\begin{array}{l}\text { Neurodegenerative } \\
\text { Disease } \\
\text { Management } \\
\text { (Future Medicine) }\end{array}$ & 88 \\
\hline McDonald \& Heath & 2009 & $\begin{array}{l}\text { Developing services for people } \\
\text { with dementia }\end{array}$ & $\begin{array}{l}\text { General } \\
\text { dementia } \\
\text { support services } \\
\text { in rural areas }\end{array}$ & UK & $\begin{array}{l}\text { Journal short report } \\
\text { feature - review of } \\
\text { service provision }\end{array}$ & $\begin{array}{l}\text { Working with Older } \\
\text { People: Community } \\
\text { Care Policy \& } \\
\text { Practice }\end{array}$ & 39 \\
\hline $\begin{array}{l}\text { The Me Myself and } \\
\text { I Club }\end{array}$ & 2018 & $\begin{array}{l}\text { The Me, Myself and I Club, } \\
\text { Briton Ferry: A case study in } \\
\text { warm humanity and } \\
\text { meaningful co-production }\end{array}$ & $\begin{array}{l}\text { Friendship club } \\
\text { and support } \\
\text { services }\end{array}$ & UK (Wales) & $\begin{array}{l}\text { Programme/service } \\
\text { report }\end{array}$ & $\begin{array}{l}\text { Me Myself and I } \\
\text { Club }\end{array}$ & 46 \\
\hline $\begin{array}{l}\text { Meiland, Dröes, De } \\
\text { Lang \& Vernooij- } \\
\text { Dassen }\end{array}$ & 2004 & $\begin{array}{l}\text { Development of a theoretical } \\
\text { model for tracing facilitators } \\
\text { and barriers in adaptive } \\
\text { implementation of innovative } \\
\text { practices in dementia care }\end{array}$ & Meeting centres & Netherlands & $\begin{array}{l}\text { Journal paper - } \\
\text { model } \\
\text { development }\end{array}$ & $\begin{array}{l}\text { Archives Of } \\
\text { Gerontology And } \\
\text { Geriatrics } \\
\text { Supplement }\end{array}$ & 55 \\
\hline
\end{tabular}




\begin{tabular}{|c|c|c|c|c|c|c|c|}
\hline $\begin{array}{l}\text { Meiland, Dröes, De } \\
\text { Lang \& Vernooij- } \\
\text { Dassen }\end{array}$ & 2005 & $\begin{array}{l}\text { Facilitators and barriers in the } \\
\text { implementation of the Meeting } \\
\text { Centres model for people with } \\
\text { dementia and their carers }\end{array}$ & Meeting centres & Netherlands & $\begin{array}{l}\text { Journal paper- } \\
\text { model test }\end{array}$ & Health Policy & 61 \\
\hline $\begin{array}{l}\text { The Mental Health } \\
\text { Foundation }\end{array}$ & 2018 & $\begin{array}{l}\text { An evaluation of the Standing } \\
\text { Together project }\end{array}$ & $\begin{array}{l}\text { Peer support } \\
\text { groups }\end{array}$ & UK & Evaluation report & $\begin{array}{l}\text { Mental Health } \\
\text { Foundation report }\end{array}$ & 73 \\
\hline $\begin{array}{l}\text { Milligan, Payne, } \\
\text { Bingley \& Cockshott }\end{array}$ & 2015 & $\begin{array}{l}\text { Place and wellbeing: shedding } \\
\text { light on activity interventions } \\
\text { for older men }\end{array}$ & Men's Sheds & UK & $\begin{array}{l}\text { Journal paper- } \\
\text { qualitative study of } \\
\text { program }\end{array}$ & Ageing \& Society & 71 \\
\hline Moore & 2002 & $\begin{array}{l}\text { Observed affect in a dementia } \\
\text { day center: Does the physical } \\
\text { setting matter? }\end{array}$ & Day centre & US & $\begin{array}{l}\text { Journal paper - case } \\
\text { study/field } \\
\text { observation }\end{array}$ & $\begin{array}{l}\text { Alzheimer's Care } \\
\text { Quarterly }\end{array}$ & 89 \\
\hline
\end{tabular}




\begin{tabular}{|c|c|c|c|c|c|c|c|}
\hline Noimuenwai & 2012 & $\begin{array}{l}\text { Effectiveness of adult day care } \\
\text { programs on health outcomes } \\
\text { of Thai family caregivers of } \\
\text { persons with dementia }\end{array}$ & $\begin{array}{l}\text { Day care } \\
\text { (Thailand) }\end{array}$ & Thailand & Dissertation/Thesis & & 78 \\
\hline NVCO & 2019 & $\begin{array}{l}\text { How To Fundraise In Tough } \\
\text { Times }\end{array}$ & $\begin{array}{l}\text { Third sector and } \\
\text { non-profit } \\
\text { organisations in } \\
\text { general }\end{array}$ & UK & Information guide & $\begin{array}{l}\text { NCVO Knowhow } \\
\text { website }\end{array}$ & 94 \\
\hline $\begin{array}{l}\text { Older People's } \\
\text { Commissioner for } \\
\text { Wales }\end{array}$ & 2018 & $\begin{array}{l}\text { Rethinking respite for people } \\
\text { affected by dementia }\end{array}$ & $\begin{array}{l}\text { Respite/day } \\
\text { services }\end{array}$ & UK (Wales) & Report & $\begin{array}{l}\text { Older People's } \\
\text { Commissioner for } \\
\text { Wales report }\end{array}$ & 47 \\
\hline $\begin{array}{l}\text { Oliver-Watkins, } \\
\text { Kendall \& } \\
\text { Matthews }\end{array}$ & 2016 & $\begin{array}{l}\text { Sow \& Grow: Report from a } \\
\text { two-year Social and } \\
\text { Therapeutic Horticultural (STH) } \\
\text { programme delivering table- } \\
\text { top gardening courses to adults } \\
\text { in the community aged } 50 \text { and } \\
\text { over }\end{array}$ & Gardening groups & UK & Evaluation report & Sow \& Grow & 67 \\
\hline
\end{tabular}




\begin{tabular}{|c|c|c|c|c|c|c|c|}
\hline Reichet \& Wolter & 2017 & $\begin{array}{l}\text { Implementing physical activity } \\
\text { programs for people with } \\
\text { dementia: Results from a } \\
\text { German study }\end{array}$ & $\begin{array}{l}\text { Sports club } \\
\text { initiatives }\end{array}$ & Germany & Poster presentation & & 44 \\
\hline Reichet \& Wolter & 2017 & $\begin{array}{l}\text { Implementing physical activity } \\
\text { programs for people with } \\
\text { dementia: Results from a } \\
\text { German study }\end{array}$ & $\begin{array}{l}\text { Sports club } \\
\text { initiatives }\end{array}$ & Germany & $\begin{array}{l}\text { Conference } \\
\text { abstract }\end{array}$ & $\begin{array}{l}\text { Innovation in Aging } \\
\text { (Supplement) }\end{array}$ & 45 \\
\hline Rio & 2018 & $\begin{array}{l}\text { A Community-Based Music } \\
\text { Therapy Support Group for } \\
\text { People With Alzheimer's } \\
\text { Disease and Their Caregivers: A } \\
\text { Sustainable Partnership Model }\end{array}$ & $\begin{array}{l}\text { Music therapy } \\
\text { group }\end{array}$ & US & $\begin{array}{l}\text { Journal paper - } \\
\text { program evaluation }\end{array}$ & $\begin{array}{l}\text { Frontiers In } \\
\text { Medicine }\end{array}$ & 62 \\
\hline $\begin{array}{l}\text { Shnall, Agate, } \\
\text { Grinberg, } \\
\text { Huijbregts, Nguyen } \\
\text { \& Chow }\end{array}$ & 2013 & $\begin{array}{l}\text { Development of supportive } \\
\text { services for frontotemporal } \\
\text { dementias through community } \\
\text { engagement }\end{array}$ & $\begin{array}{l}\text { Day program for } \\
\text { FTD (plus online } \\
\text { groups and } \\
\text { resources for } \\
\text { family carers) }\end{array}$ & Canada & $\begin{array}{l}\text { Journal paper- } \\
\text { review of initiatives }\end{array}$ & $\begin{array}{l}\text { International } \\
\text { Review of } \\
\text { Psychiatry }\end{array}$ & 96 \\
\hline
\end{tabular}




\begin{tabular}{|c|c|c|c|c|c|c|c|}
\hline Solutions Research & 2016 & $\begin{array}{l}\text { Public perceptions and } \\
\text { experiences of community- } \\
\text { based end of life care } \\
\text { initiatives: a qualitative } \\
\text { research report }\end{array}$ & $\begin{array}{l}\text { Community- } \\
\text { based support } \\
\text { initiatives of all } \\
\text { kinds }\end{array}$ & UK & Report & $\begin{array}{l}\text { Public Health } \\
\text { England report }\end{array}$ & 56 \\
\hline $\begin{array}{l}\text { Strandenæs, Lund } \\
\text { \& Rokstad }\end{array}$ & 2018 & $\begin{array}{l}\text { Experiences of attending day } \\
\text { care services designed for } \\
\text { people with dementia - a } \\
\text { qualitative study with } \\
\text { individual interviews }\end{array}$ & Day care & Norway & $\begin{array}{l}\text { Journal paper- } \\
\text { qualitative study }\end{array}$ & $\begin{array}{l}\text { Aging \& Mental } \\
\text { Health }\end{array}$ & 40 \\
\hline Thrive & 2012 & $\begin{array}{l}\text { Growing4life - A Thrive } \\
\text { Community Gardening Project: } \\
\text { A practical guide to setting up } \\
\text { a community gardening project } \\
\text { for people affected by mental } \\
\text { ill health }\end{array}$ & Gardening groups & UK & $\begin{array}{l}\text { Information/guide } \\
\text { booklet }\end{array}$ & $\begin{array}{l}\text { Thrive (The Society } \\
\text { for Horticultural } \\
\text { Therapy) }\end{array}$ & 74 \\
\hline Tuppen & 2012 & $\begin{array}{l}\text { The benefits of groups that } \\
\text { provide cognitive stimulation } \\
\text { for people with dementia }\end{array}$ & $\begin{array}{l}\text { Cognitive } \\
\text { stimulation clubs }\end{array}$ & UK & $\begin{array}{l}\text { Journal article - } \\
\text { overview of } \\
\text { intervention }\end{array}$ & $\begin{array}{l}\text { Nursing Older } \\
\text { People }\end{array}$ & 72 \\
\hline
\end{tabular}




\begin{tabular}{|c|c|c|c|c|c|c|c|}
\hline Tuppen \& Jones & 2015 & $\begin{array}{l}\text { Cogs Clubs: a helpful activity in } \\
\text { early dementia }\end{array}$ & $\begin{array}{l}\text { Cognitive } \\
\text { stimulation clubs }\end{array}$ & UK & $\begin{array}{l}\text { Specialist news } \\
\text { article }\end{array}$ & $\begin{array}{l}\text { Journal of } \\
\text { Dementia Care }\end{array}$ & 75 \\
\hline $\begin{array}{l}\text { Van Haeften-van } \\
\text { Dijk, Meiland, van } \\
\text { Mierlo \& Dröes }\end{array}$ & 2015 & $\begin{array}{l}\text { Transforming nursing home- } \\
\text { based day care for people with } \\
\text { dementia into socially } \\
\text { integrated community day } \\
\text { care: Process analysis of the } \\
\text { transition of six day care } \\
\text { centres }\end{array}$ & Meeting centres & Netherlands & $\begin{array}{l}\text { Journal paper - } \\
\text { process evaluation }\end{array}$ & $\begin{array}{l}\text { International } \\
\text { Journal of Nursing } \\
\text { Studies }\end{array}$ & 79 \\
\hline $\begin{array}{l}\text { Van Mierlo, } \\
\text { Chattat, Evans, } \\
\text { Brooker, Saibene, } \\
\text { Gamberini, Farina, } \\
\text { Scorolli, Szcześniak, } \\
\text { Urbańska, } \\
\text { Rymaszewska, } \\
\text { Dröes \& Meiland }\end{array}$ & 2018 & $\begin{array}{l}\text { Facilitators and barriers to } \\
\text { adaptive implementation of } \\
\text { the Meeting Centers Support } \\
\text { Program (MCSP) in three } \\
\text { European countries; the } \\
\text { process evaluation within the } \\
\text { MEETINGDEM study }\end{array}$ & Meeting centres & $\begin{array}{l}\text { Netherlands, Italy, } \\
\text { Poland, UK }\end{array}$ & $\begin{array}{l}\text { Journal paper - } \\
\text { program evaluation }\end{array}$ & $\begin{array}{l}\text { International } \\
\text { Psychogeriatrics }\end{array}$ & 41 \\
\hline Williams \& Roberts & 1995 & $\begin{array}{l}\text { Friends in passing: social } \\
\text { interaction at an adult day care } \\
\text { center }\end{array}$ & $\begin{array}{l}\text { Adult day care } \\
\text { centre }\end{array}$ & US & $\begin{array}{l}\text { Journal paper - } \\
\text { participant } \\
\text { observation }\end{array}$ & $\begin{array}{l}\text { International } \\
\text { Journal Of Aging \& } \\
\text { Human } \\
\text { Development }\end{array}$ & 68 \\
\hline
\end{tabular}




\begin{tabular}{|l|l|l|l|l|l|l|l|}
\hline $\begin{array}{l}\text { Wimo, Wallin, } \\
\text { Lundgren, } \\
\text { Ronnback, Asplund, } \\
\begin{array}{l}\text { Mattsson \& Krakau } \\
\text { (see also Clarkson } \\
\text { et al 2017) }\end{array}\end{array}$ & 1990 & $\begin{array}{l}\text { Impact of Day Care on } \\
\text { Dementia Patients-Costs, } \\
\text { Well-being and Relatives' } \\
\text { Views }\end{array}$ & $\begin{array}{l}\text { Specialist day } \\
\text { care }\end{array}$ & Sweden & $\begin{array}{l}\text { Journal paper - cost } \\
\text { analysis }\end{array}$ & Family Practice & 95 \\
& & & & & & \\
& & & & \\
\hline
\end{tabular}




\section{Supplementary file 5: Diagrams of factors involved in each critical area}

Text colour key: Black text = sub-outcome directly impacting upon "getting/keeping" Green text = likely to help sub-outcome Red text = likely to hinder sub-outcome

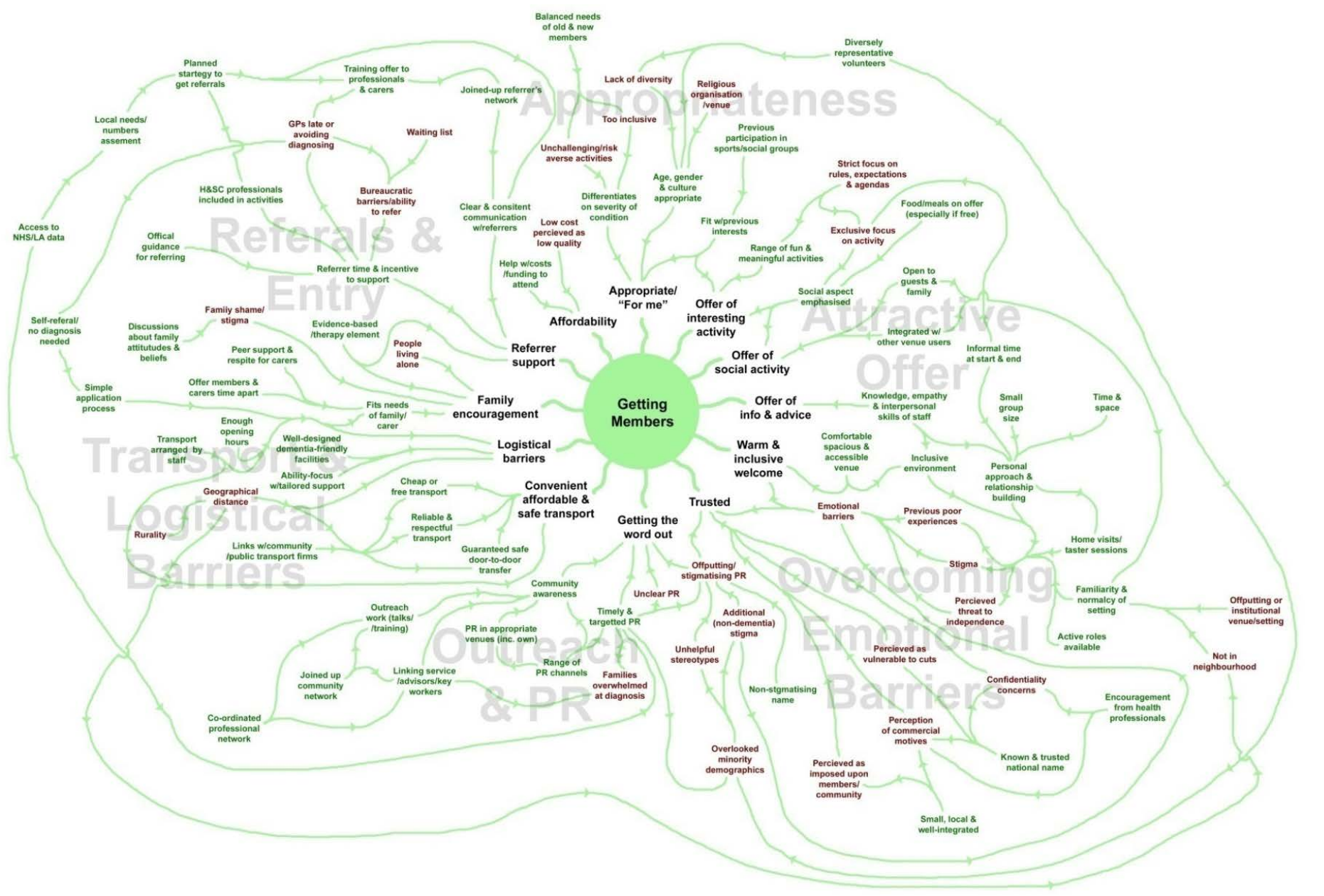




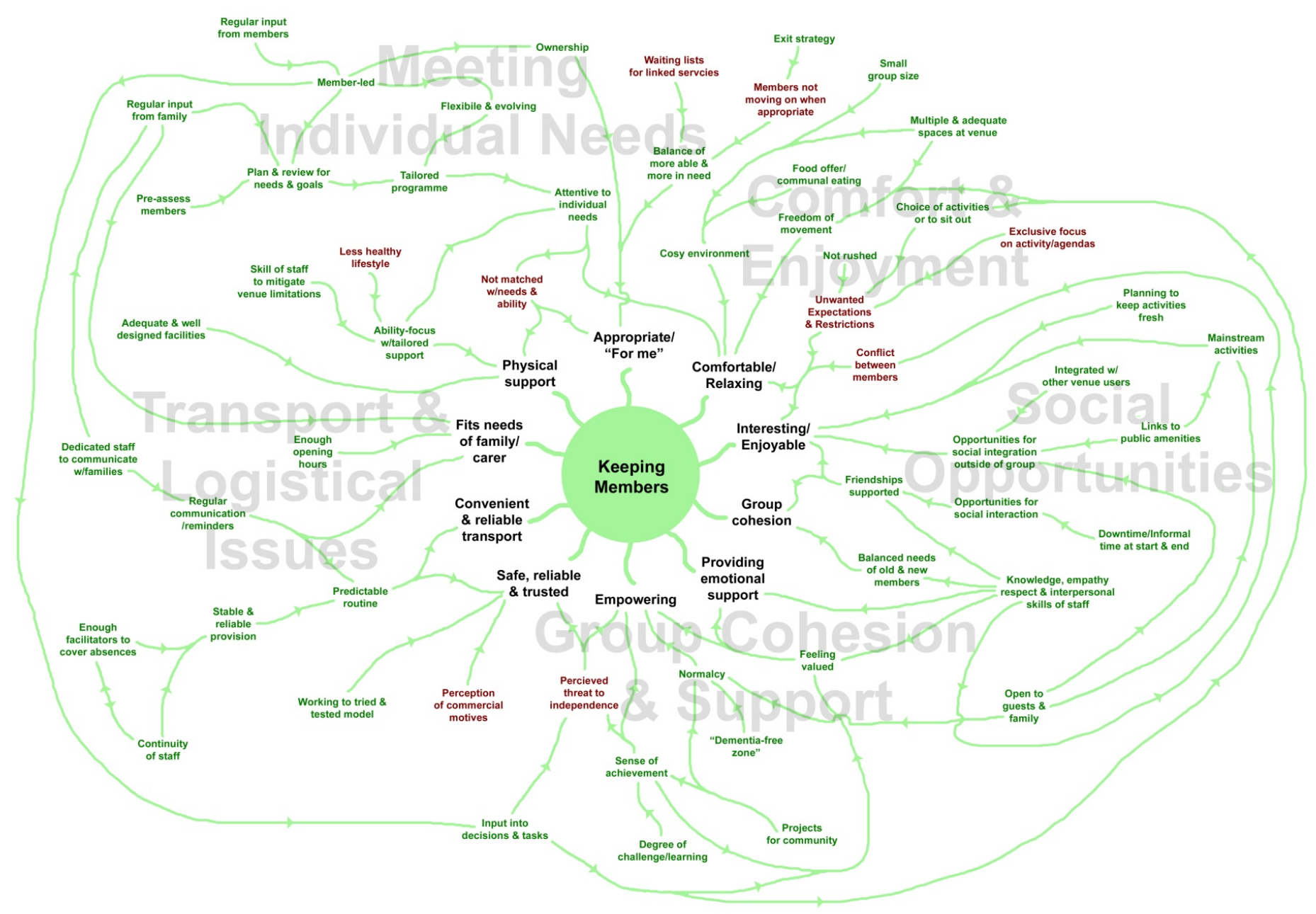




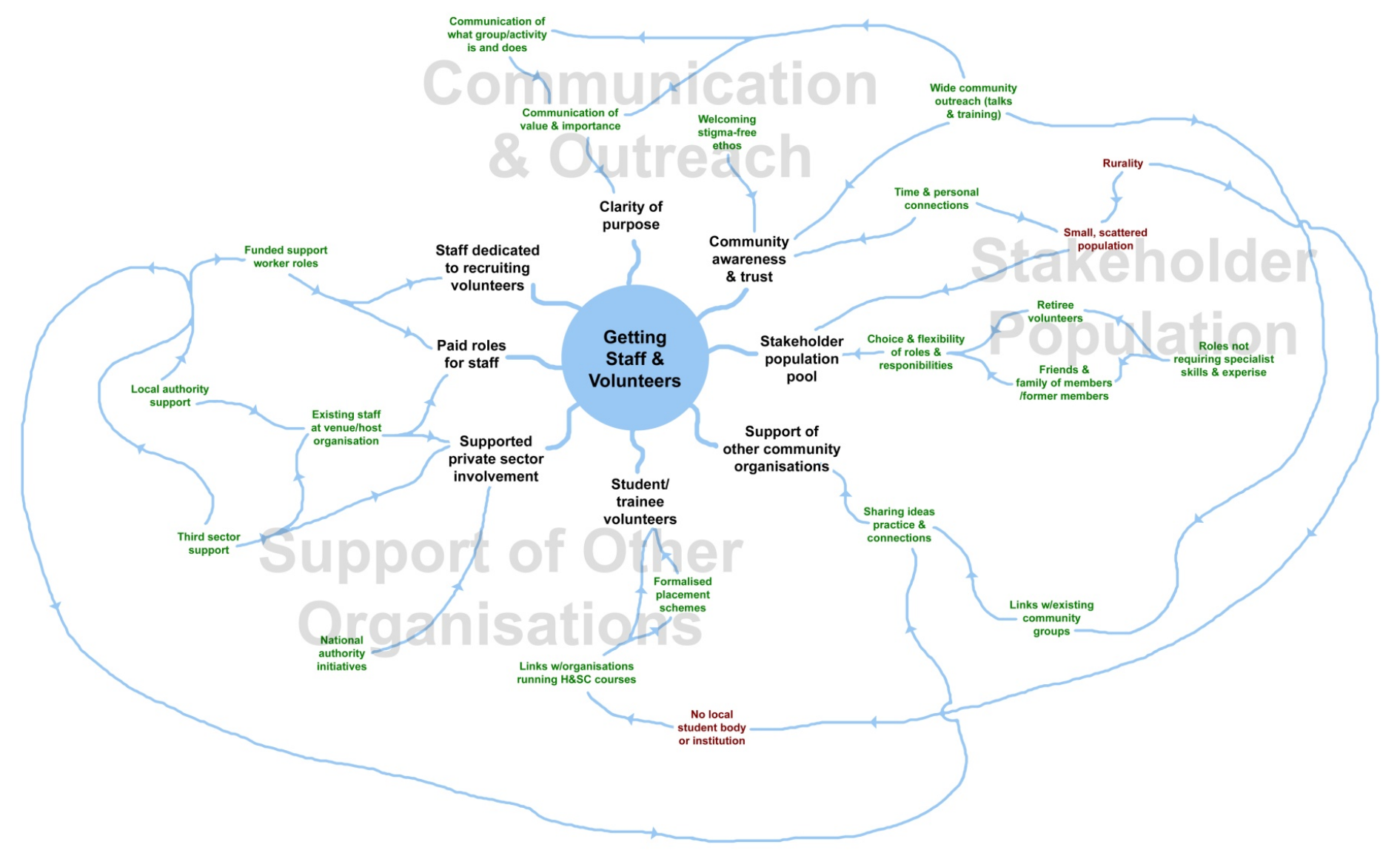




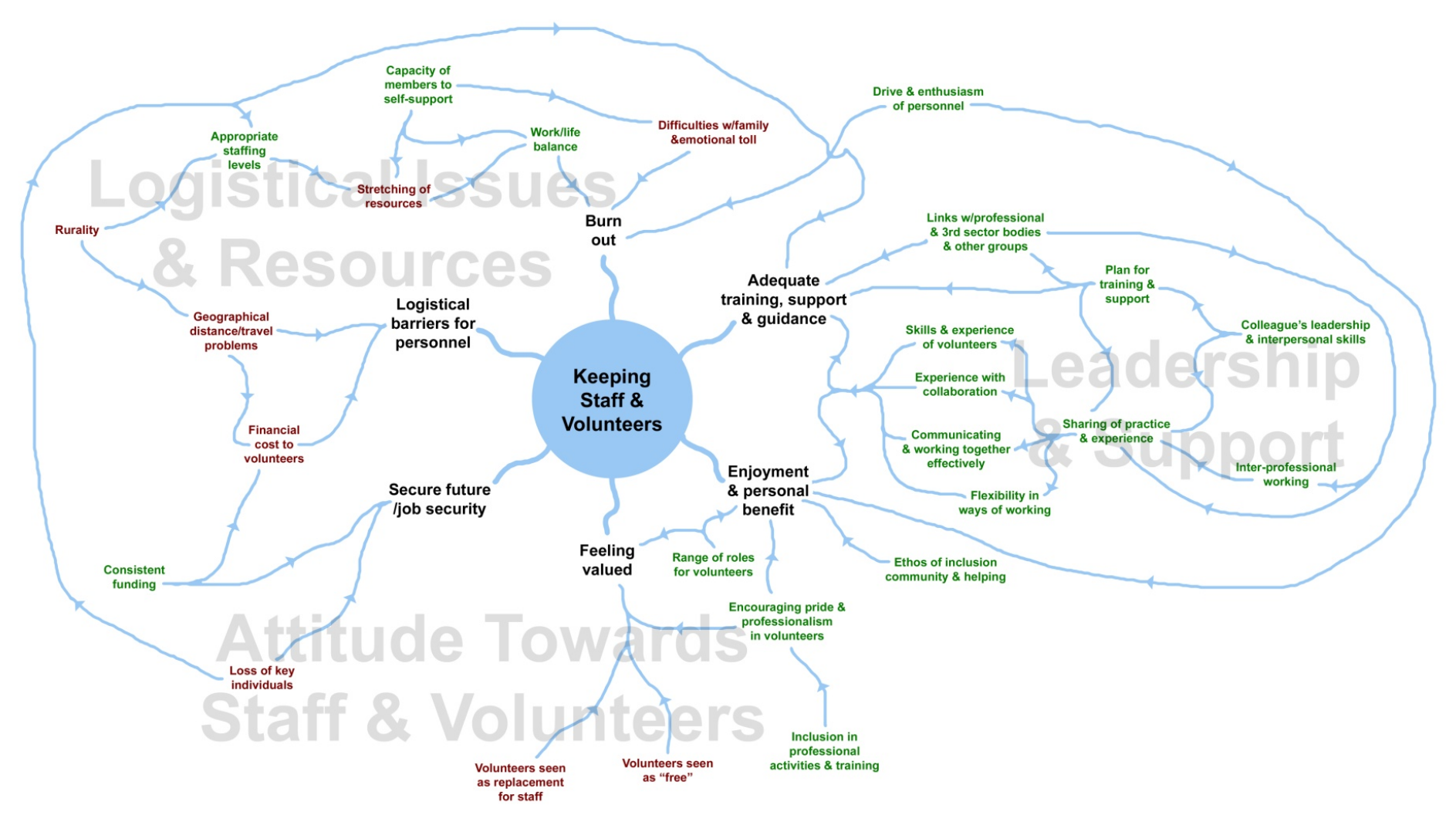




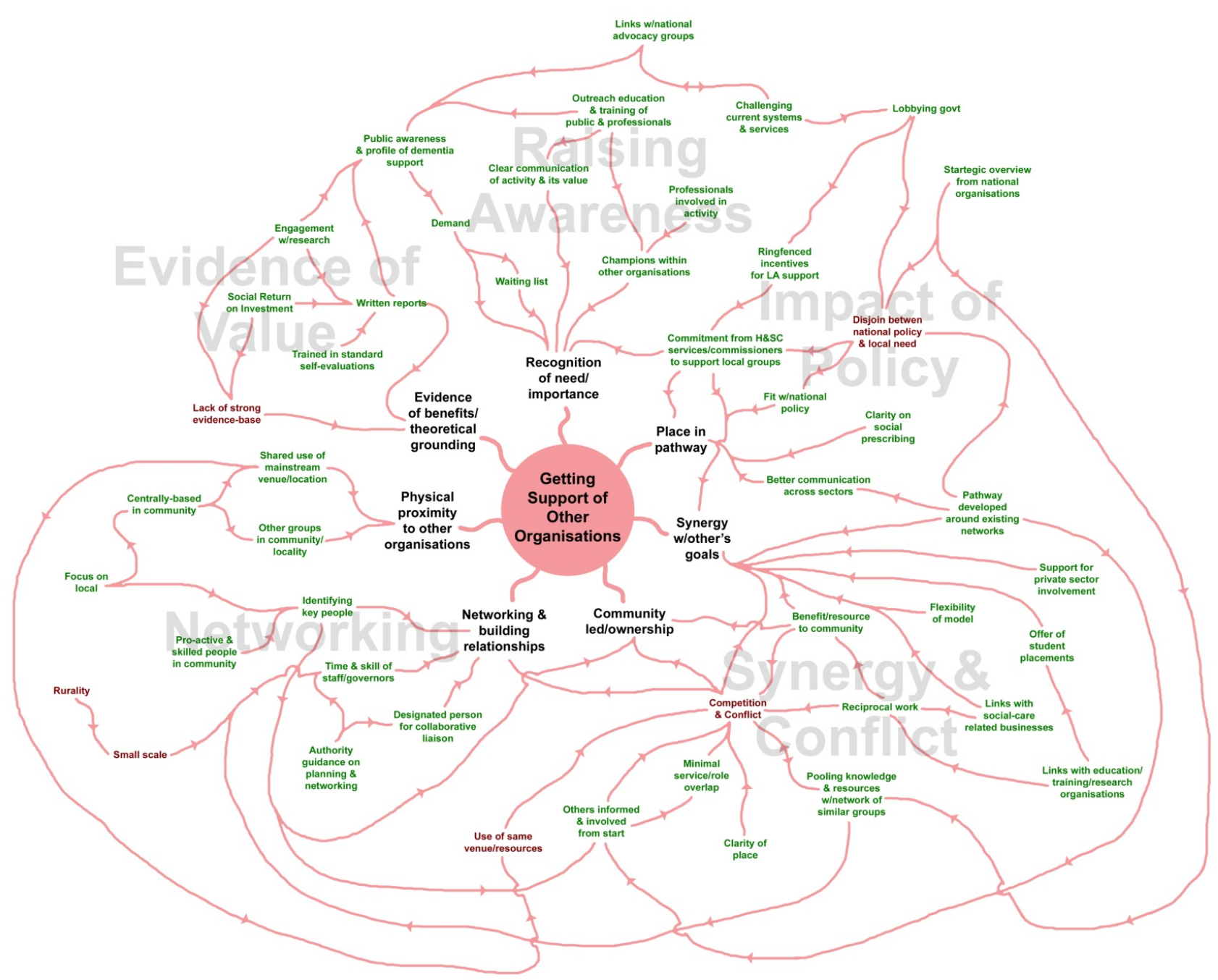




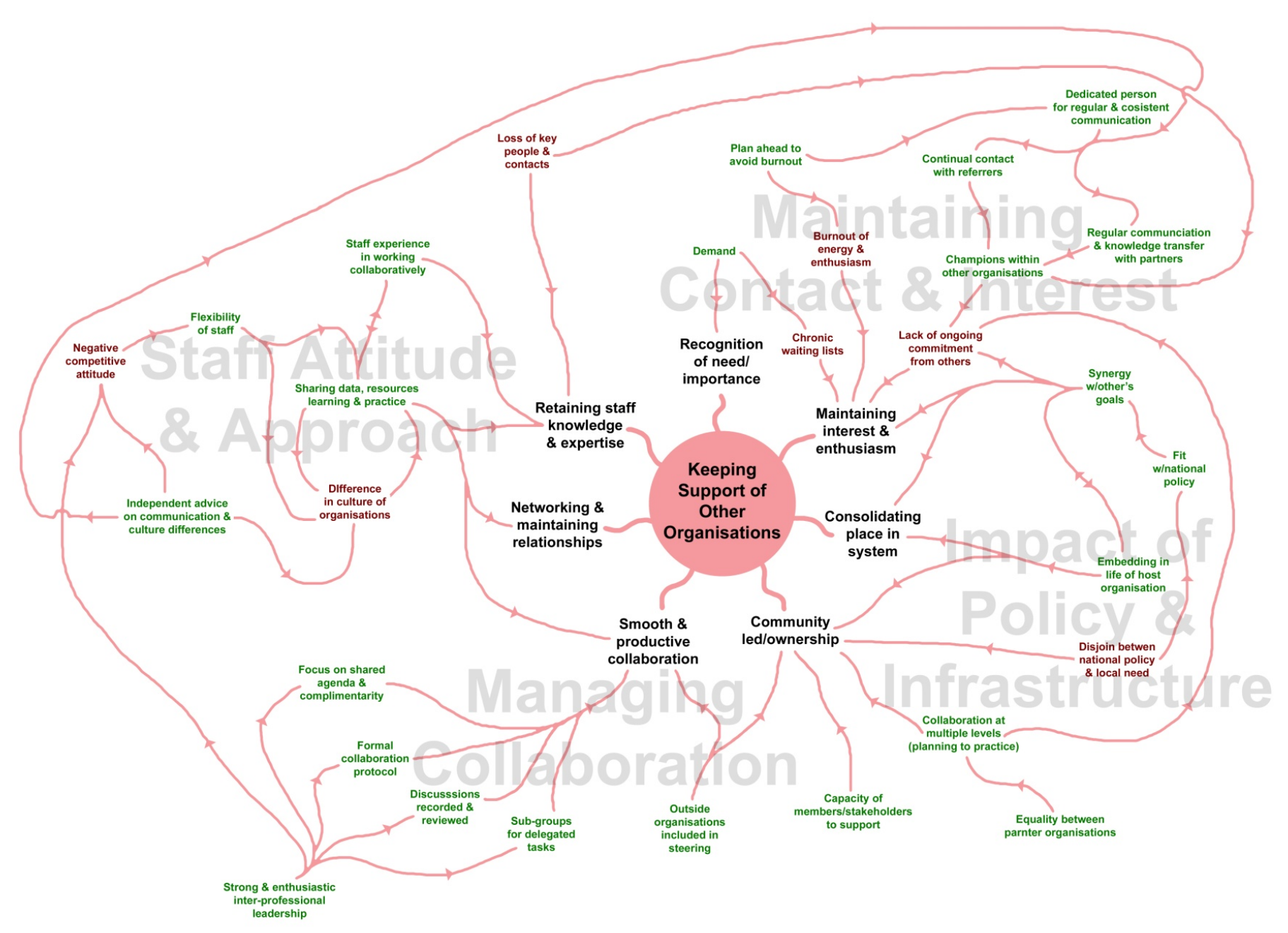




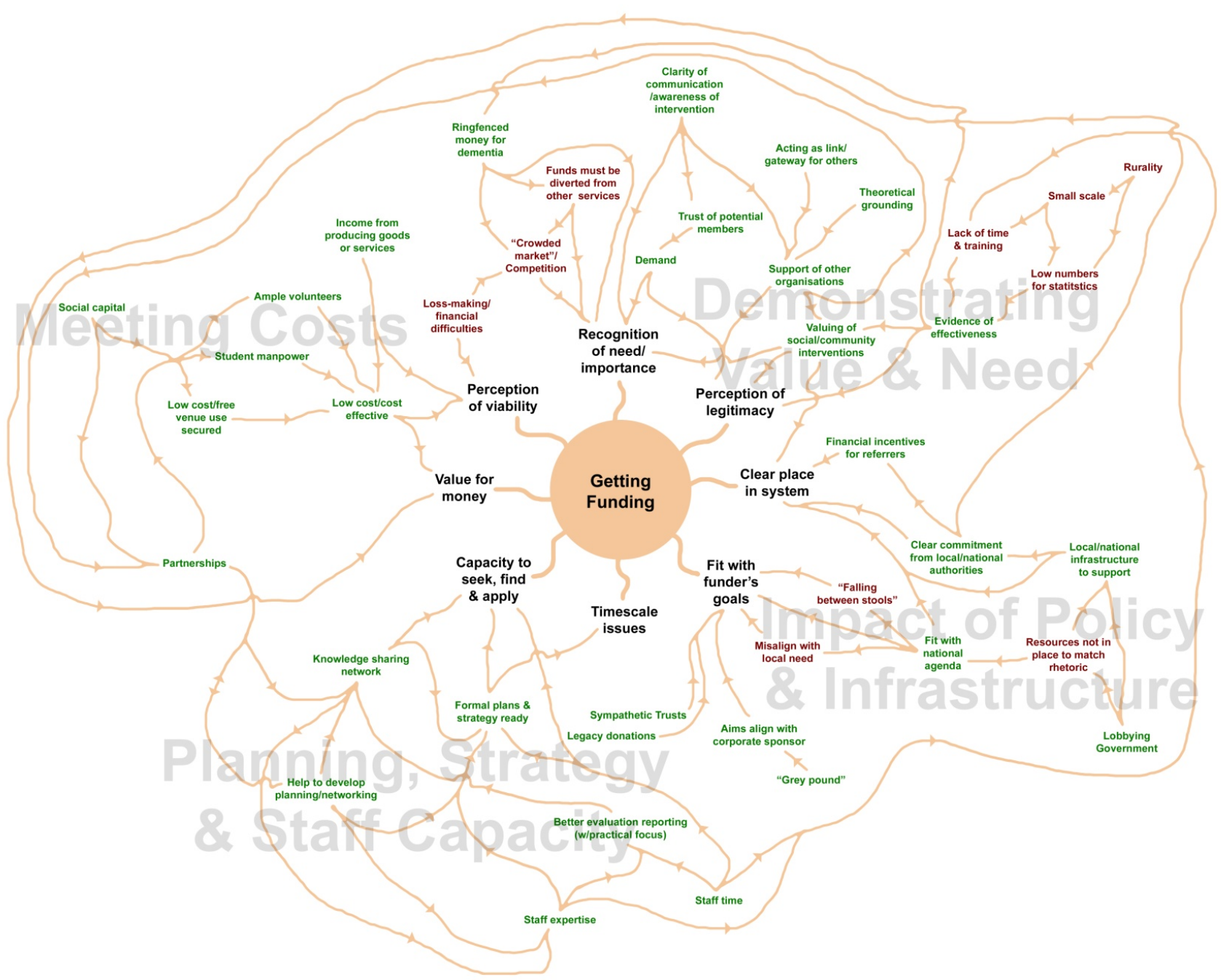




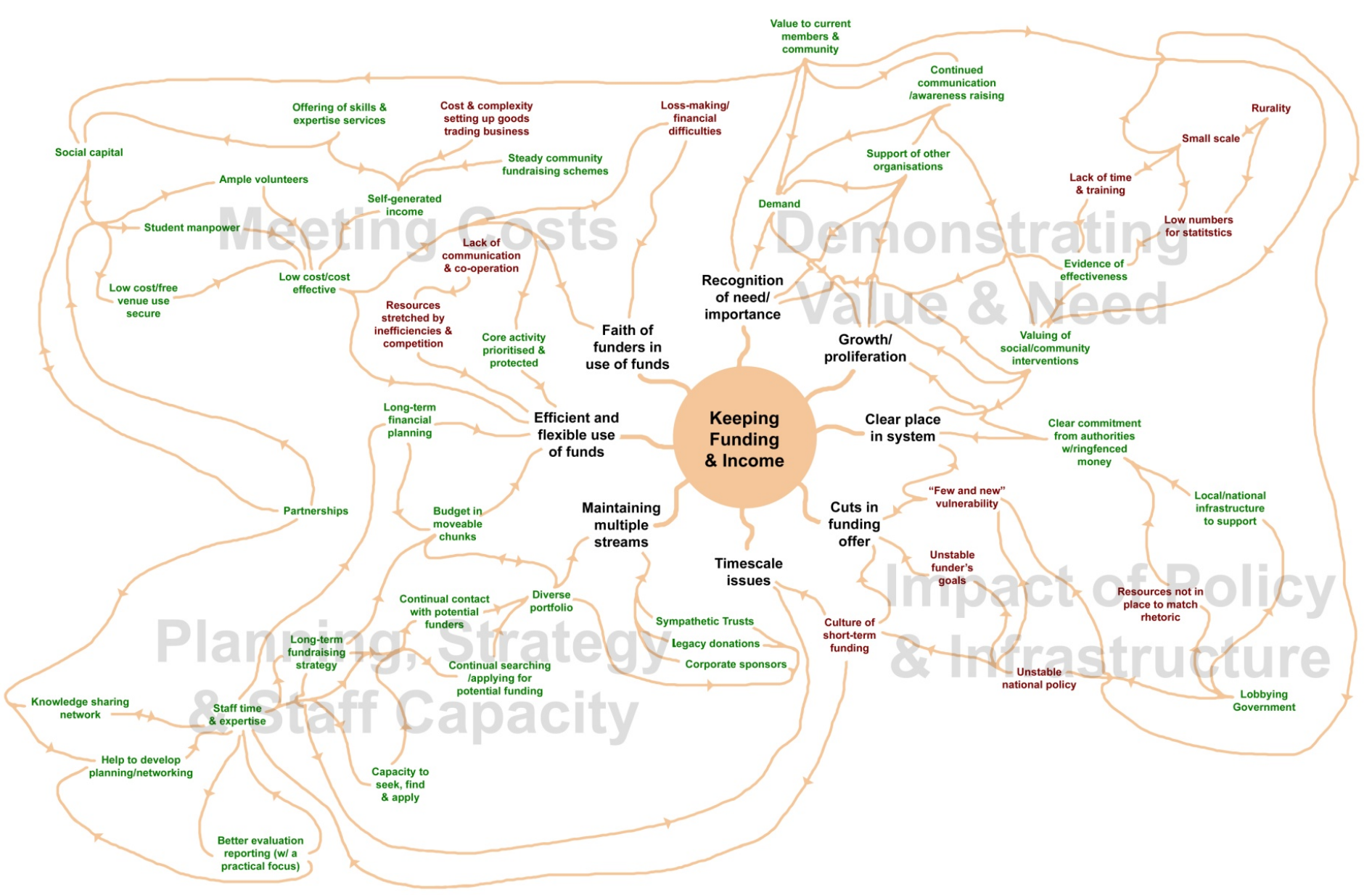




\section{Supplementary file 6: Full list of CMOCs}

\section{Getting Members}

CMOC 1: If the social aspect of an intervention is emphasised (C), then a wider range of people are likely to be interested (O), as a desire for social connection and activity is more universal than interest in a niche and potentially intimidating activity (M). $[40,48,50,57,58,62,64,75]$

CMOC 2: If food is offered $(C)$, then people are more likely to attend $(\mathrm{O})$, because the enjoyment of good food is universal and communal eating is associated with comfort, relaxation and social connection (M). [40,59]

CMOC 3: If facilitators are knowledgeable and empathetic, with good interpersonal skills (C), an initiative will be perceived as more welcoming and inclusive $(\mathrm{O})$, as they will be better at understanding needs, engaging and building trust with potential members and their families (M). [36,37,38,39,40,41]

CMOC 4: If an initiative has an informal, unrushed and warm welcome on first visit (C), then people are more likely to want to return (O), as they are more likely to find the experience relaxing and enjoyable, not uncomfortable and intimidating $(M)$. $[40,42,43,44,45]$

CMOC 5: If potential members have had poor previous experiences with groups or activities (dementia related or not) (C), they may not want to try another group or activity $(0)$, because they think the experience will be similar and will want to avoid it $(M)$. [37,41,46,47]

CMOC 6: If time is taken for personal contact, home visits or taster sessions with potential members (C), then people are more likely to come (O), as they will feel more familiar with the initiative and more trusting of those running it $(\mathrm{M})$. $[36,38,47,48,49,50]$

CMOC 7: If an initiative is familiar and trusted, or local and well integrated with other organisations in the community (C), then people are more likely to come (O), as its links to familiar things that they trust will make it less intimidating (M). $[37,41,42,48,51,52,53,54,55,56]$

CMOC 8: If an intervention is based in familiar surroundings in, and open to, the community (C), then people are more likely to come (O), because potential members will find the normalcy, lack of stigma and chance for social integration appealing (M). $[38,41,48,52,57,58,59,60,61,62]$

CMOC 9: If a venue is dementia-friendly, comfortable and accessible (C), people are more likely to come (O), as they will not have concerns about comfort or access (M). [48,55,63,64]

CMOC 10: If an intervention is recommended by trusted family members and health professionals $(\mathrm{C})$ people are more likely to go $(\mathrm{O})$, as they will trust their judgement that it will be of benefit to them (M). [54,65]

CMOC 11: If discussion/training is held with families, carers and health professionals about their attitudes and beliefs towards dementia (C), they may be more likely to successfully encourage the person they care for to try an intervention (O), because they will understand dementia and be better able to overcome stigma and emotional barriers (M). [36,54,56,65]

CMOC 12: If evidence of an intervention's therapeutic benefits is made clear to families and care partners (C), then people are more likely to attend $(\mathrm{O})$ as families and care partners will have confidence in the intervention so be more likely to encourage them to go (M). $[38,41,75,78]$

CMOC 13: If there is support for family/care partners alongside the intervention (C) then people are more likely to attend $(\mathrm{O})$, as family and care partners will feel more able and inclined to attend themselves and encourage those they care for $(\mathrm{M}) .[42,48,56,58,76,77,79]$

CMOC 14: If an initiative is in a close-knit community with where there is stigma about dementia (C), then people and their families may be put off coming $(0)$, as they may be concerned about confidentially and word of their condition (or that of their family member) getting out (M). $[47,56,62,73]$

CMOC 15: If an initiative provides enjoyable, meaningful activities (C), then this is likely to attract members (O), as doing them will provide a reason and motive for many to attend initially, even if they stay on for other benefits (M). [41,44,45,50,64,67,70,71,72,83]

CMOC 16: If an initiative provides normalised, mainstream activities (C), then they are likely to attract members $(0)$, as they will have resonance with people's previous interests, experience and history that would like to continue in some form (M). $[46,48,57,58,65,67,71,81]$

CMOC 17: If an initiative offers a range of different activities and services (C), then people are more likely to attend (O), as the initiative will appeal to a wider range of people with a range of needs (M). [47,48,62,84]

CMOC 18: If potential members' culture, ethnicity and language are acknowledged and catered for within the initiative (C), then they are more likely to come $(0)$, as they will feel more comfortable and valued $(\mathrm{M}) .[47,56,63,69,80]$

CMOC 19: If there is a lack of diversity (of members and personnel) or pandering to stereotypes (C), then people may be put off coming $(\mathrm{O})$, as they may have concerns about discrimination and stigma beyond dementia (M). [53,56,70,77]

CMOC 20: If the initiative is run by a religious organisation or in religious venue (C), then people may be put off coming (O), if they are not of that religion or cultural background (M). [56,82]

CMOC 21: If a group is too inclusive when not appropriate (C), this can alienate potential target members (O), as they will feel it will not be focussed on their specific needs (M). [37,60,62]

CMOC 22: If an initiative differentiates activities and roles for members by ability (C), then this can encourage potential members to attend $(\mathrm{O})$, as they will feel there is an appropriate place for them rather than everyone being lumped in together $(\mathrm{M})$. [48,79] 
CMOC 23: If an intervention is risk averse or underestimates members' abilities and avoids challenge (C), then potential members will be put off (O), because they will see its activities as too easy, boring or not appropriate for them (M). $[63,64,69,73]$

CMOC 24: If an intervention is ability-focussed with tailored support and sensitive design of facilities (C), it is more likely to persuade potential members to attend $(\mathrm{O})$ as they will be encouraged and supported to overcome physical impairments and negative attitudes (M). $[43,58,62,64,69]$

CMOC 25: When an intervention can offer practical advice, information and links to services that can help people (C), then it is more likely to attract members/service users $(0)$, as they will be able to see that it has something to offer them that will meet their most immediate and pressing needs (M). [42,44,45,54,73,85]

CMOC 26: If safe, supported transfer from home to venue can be guaranteed (C), then people will be more likely to come (O), because they will be more likely to overcome any concerns about going out and getting to a group or activity session (M). $[36,38,44,45,47,60,64,65,85,73]$

CMOC 27: If the transport available isn't appropriate, reliable and respectful of people with dementia (C), then people will not come (O), as will not want to use that transport to get there (M). [37,47,49,64,76,77,82]

CMOC 28: If transport costs are significant and there is no financial support (C), then people will not come (O), as they will not be able to afford the transport costs (M). [36,38,56,59,64,76,78,82]

CMOC 29: If the venue is not in people's own neighbourhoods, is geographically distant or hard to reach (C) then people will not come (O) as they will find it difficult or intimidating to get there $(M) .[49,60,61,86]$

CMOC 30: If an initiative forms links with community and public transport/taxi firms (C), then this will attract members $(O)$, as they will find it less difficult or intimidating to travel to the venue (M). [48,76,77]

CMOC 31: If referrers are not made clearly aware of the added value, target population, ethos and activities of an intervention (C), then they will be less likely to refer appropriately $(0)$, as they will not understand the value of it to their clients $(M)$. $[41,51,61,75,79]$

CMOC 32: If there is constant contact and collaboration with potential referrers $(C)$, then they are more likely to refer members $(\mathrm{O})$, as they will build a relationship with the intervention that will mean they are better able to understand and remain alert to it (M). $[46,51,54,55,74,75,79]$

CMOC 33: If PR materials are not available in the right places or presented to people in the right circumstances (C), then they will not try an intervention $(\mathrm{O})$, because they will not access those materials to find out about an intervention's potential value to them (M). $[36,47,56,78,82]$

CMOC 34: If PR materials are not in an understandable and appropriate format and tone (C), then people will not try an intervention (O), as they will find the materials too off-putting to engage with (M). [38,49,56,61,67,73,74,80]

CMOC 35: If PR materials do not make clear the specifics of an intervention, what to expect and how to attend (C), then people will be less likely to come (O), as they may be anxious due to uncertainties over what they will have to do and its value to them $(M)$. [41,48,51,56,89]

CMOC 36: If an intervention has a stigma-free name that resonates with its target population (C), then people are more likely to come (O), as they will have confidence that they will be treated with respect and not suffer stigma when they go (M). $[38,46,56,59,66,72]$

CMOC 37: If the local community is fragmented with no local welfare organisation to distribute information (C), then people will be less likely to come (O), as it will be more difficult to get the word out to the right people in the community (M). [37,56,61]

CMOC 38: If in intervention forms links with existing groups, organisations and venues serving same demographic (C), then people will be more likely to come (O), as information and marketing materials will be more likely to reach them (M). $[48,54,62,67,83]$

CMOC 39: If all those involved in a person's care work together to collate and co-ordinate information (C), then people will be more likely to come $(\mathrm{O})$ as information and marketing materials will reach them more efficiently $(\mathrm{M})$. [36,61]

CMOC 40: If there is a dedicated linking, contact or health care adviser service $(\mathrm{C})$ then people will be more likely to come $(0)$ as information and marketing materials will reach them more efficiently (M). [36,38,44,45,47,56,75,80,88]

CMOC 41: If awareness of the needs of people dementia and of how an intervention can meet them is raised in the community in genera (C), then people will be more likely to come (O), as stigma will be reduced and the value of the intervention communicated through word of mouth (M). [36,37,38,46,47,48,51,54,56,59,67,70,83,84,87]

CMOC 42: If GPs were given more incentive and guidance for social prescribing (C), then they would refer more people (O), because they would have a vested interest and confidence in doing so (M). [47,69]

CMOC 43: If there are significant bureaucratic problems with referring (such as chronic waiting lists, area border issues or the need for signed consent) (C), then professionals will be less likely to refer $(O)$, as they will anticipate difficulties that will thwart their attempt to refer (M). $[47,61,80,88]$

CMOC 44: If GPs do not diagnose dementia until people are at later stages (C), then they will not refer people to community initiatives (O) as they will not see initiatives targeted towards those at earlier stages still able to live at home as appropriate for those they are diagnosing (M). [76,79]

CMOC 45: If an intervention waives the need for a diagnosis and accepts self-diagnosis (C), more people will come (O), as this will encourage a wider range of potential members and avoid excluding people who might benefit (M). [38,57,79,83]

CMOC 46: If an initiative's membership application process is not simple, clear, concise and easy (C), then people will not come (O), as the difficulty in applying will put them off joining (M). [38,44,45,74] 


\section{Keeping Members}

CMOC 47: If there is group cohesion and mutual trust between members $(C)$, then a group is more likely to sustain (O), because members will feel more solidarity and investment in the group (M). [65]

CMOC 48: If friendships between members are encouraged, recognised and supported by staff and activities (C), then people are likely to keep coming $(0)$, as they will feel more supported, comfortable and engaged, and able to support each other $(\mathrm{M})$. $[43,54,66,67,68]$

CMOC 49: If an intervention is too focussed on agendas, rules and expectations (C), then people may stop coming (O), because they fee pressured, restricted and unable to relax and enjoy the social and emotional benefits important to them (M). $[44,45,63,67,69,70,71]$

CMOC 50: If the pace of activity through the day/session is too fast and strict (C), then people may stop coming (O), because they will struggle to stay engaged and will not enjoy themselves (M). [43,48,57,61,72]

CMOC 51: If ample informal time is made for socialising, peer support and feedback (C), then members are more likely to keep coming (O), as they will be more likely to feel comfortable and supported (M). $[40,43,48,50,58,62,65,67,69,70,71,72,73,74,75]$

CMOC 52: If there is opportunity to have communal eating and relaxing in a "cozy" environment (C), then members are more likely to keep coming $(0)$, as this will provide comfort and foster group cohesion. [40,65]

CMOC 53: If there is regular social integration with others outside of the group (C), then members are more likely to keep coming $(0)$, as they will feel more connected and less stigmatised (M). [38,41,47,48,49,52,54,59,61,62,66]

CMOC 54: If activities are mainstream and involve others without dementia (e.g. family/carers or locals from the community) (C), then members are more likely to keep coming $(0)$, as they will feel activities are more normalised, reducing stigma and increasing enjoyment (M). $[37,46,47,48,54,57,61,76]$

CMOC 55: If an intervention is treated as a "dementia free zone" where talk is not about a person's condition or medical issues (unless they want to raise them) $(C)$, then people are more likely to keep coming $(\mathrm{O})$, as they will find the environment more normalising and less stigmatising (M). [58,71]

CMOC 56: If an initiative contains projects which enable members to contribute to helping others in the community (C), then people are more likely to keep coming $(0)$, because they will feel valued, useful and empowered $(M)$. $[47,67]$

CMOC 57: If an initiative has links to existing mainstream public amenities (C), then people are more likely to keep coming (O), as they will recognise it gives them access to wider networks of support and friendship (M). [90]

CMOC 58: If members are involved in group decision-making and setting expectations (C), then people are more likely to keep coming (O), because they will feel ownership and investment in the group and confidence that the group is tailored towards their needs (M). $[43,52,65,66,71,74,84]$

CMOC 59: If regular feedback meetings are held to "tune" an intervention to the wants and needs of members (C), then people are more likely to keep coming $(\mathrm{O})$, as activities will be kept appropriate and evolve to suit the membership (M). [41,44,45,48,55,67,91]

CMOC 60: If individuals are allowed to make their own decisions about what they do or don't do during a session (C), then they will be more likely to keep coming $(0)$, as they will feel their independence and freedom is respected and their voice heard $(\mathrm{M})$. [36,40,43,63,91]

CMOC 61: If staff treat people respectfully as equals and relate personally (C), then people are more likely to keep coming $(0)$, because they will feel staff and the group as a whole understands them and their needs(M). [40,42,44,45,46,63,65]

CMOC 62: If strategies are planned to review individual progress and involvement (C), then people are more likely to keep coming (O), as they are more likely to remain engaged and feel part of the group as a whole $(\mathrm{M}) .[43,59,74]$

CMOC 63: If personnel listen to and act upon regular input from family and caregivers (C), then people are more likely to keep coming (O) as they will appreciate the increased personalisation and sensitivity to their needs (M). [41,59,61,63,91]

CMOC 64: If an initiative does not pay attention to the needs of family and care partners (C), then people are less likely to keep coming $(\mathrm{O})$, because there may be unaddressed logistical difficulties for the family or carers such as fit with work or transport issues (M). $[38,44,45,47,54,60,61,73,78]$

CMOC 65: If an initiative can open for more hours and help arrange transport (C), then people are more likely to come (O), as this will take the pressure off family members and carers to be flexible and arrange things, and bypass logistical difficulties $(M) .[44,45,48,49,50,57,78]$

CMOC 66: If members who are no longer the target for the intervention stay on because there is no exit strategy or onward service capacity $(\mathrm{C})$, then this can discourage target members from continuing to attend $(\mathrm{O})$, as they may feel the service is too stretched to meet their needs (M). $[41,43,61]$

CMOC 67: If an initiative does not cater equally both for new members and older members whose condition has progressed (C), then this can discourage one group or the other from continuing to attend $(0)$, as they will feel the initiative is more focussed upon the other group hence not appropriate for them (M). $[66,71,75]$

CMOC 68: If a group or activity is not matched with members' interests and ability (C), then members may stop attending $(\mathrm{O})$, as they will feel it is not appropriate for them or meeting their needs (M). [46,48,49,78]

CMOC 69: If activities involve a degree of challenge or learning (C), then members may be more likely to keep coming (O), as they will fee empowered and have a sense of achievement (M). [37,47,58,67,71,76] 
CMOC 70: If an intervention pre-assesses members and plans strategies to meet their individual needs (C), then members are more likely to keep coming $(0)$, because activities and support will be more likely to be appropriate for them (M). $[43,44,45,57,59,60,74]$

CMOC 71: If a venue is comfortable, familiar and stable, with adequate space and facilities (C), then people are more likely to keep coming (O), as they will feel relaxed, secure and at home there (M). [43,48,55,63]

CMOC 72: If a venue has multiple spaces within it (C), then people are more likely to feel comfortable there (O), as they will be able to move around and have a choice of activities, environments, social sub-groups or levels of involvement in activity (M). [63,89]

CMOC 73: If sessions are regular, routine and structured (C), then members will be more likely to keep coming (O), as they will feel comfortable and secure in the familiarity and reliability of proceedings (M). [38,40,43,47,48,65,72,73,75]

CMOC 74: If the venue and timings remain reliably the same $(\mathrm{C})$ then members are more likely to keep coming $(\mathrm{O})$, as it will become part of their routine (M). $[43,48]$

CMOC 75: If there is no continuity of staff or not enough staff to ensure reliable provision (C), then members may be less likely to keep coming $(\mathrm{O})$, as they will find it difficult to have confidence and build trust in the intervention and its staff $(\mathrm{M}) .[36,47,66]$

CMOC 76: If an intervention works to a tried and tested model (C), then members are more likely to feel secure (O), as that model will provide a structure that works (M). [61]

CMOC 77: If there are not new ideas and some variety planned across the calendar (C), then members may stop coming (O), because they may feel the group/activities have become stale and boring (M). [37,43,67]

\section{Getting Staff and Volunteers}

CMOC78: If an initiative engages in community outreach such as talks and training with other groups and at events (C), then this will help attract volunteers $(0)$, because the initiative's profile will be raised with wide range of stakeholders in the community $(\mathrm{M})$. [46,59,83]

CMOC79: If awareness is raised in the community about the activities and benefits of a what an initiative does (C), then it will be more likely to attract appropriate personnel $(0)$, as potential staff and volunteers will understand its value to service users and what they can do to help (M). [56,61,89,91]

CMOC80: If an initiative has links with like-minded groups (C), then they may get help finding and training staff volunteers $(\mathrm{O})$, as they will be able to share ideas and practice on what is successful (M). [50,91]

CMOC81: If an initiative approaches established community organisations and authorities (third sector, faith or local authority) (C), they are more likely to get help with finding volunteers $(\mathrm{O})$, as these organisations are likely to have access to an existing volunteer workforce or contacts that could help (M). [69,77]

CMOC82: If an initiative has links with professional, third sector or educational bodies (C), they may help with creating a more skilled workforce $(\mathrm{O})$, because they may have the remit provide training for staff and volunteers $(\mathrm{M})$. [80,84]

CMOC83: If an initiative is hosted by a public venue or local club (C), this may help with staffing $(0)$, as the venue or club may have existing staff who can help with running things (M). [48,58,67,69]

CMOC84: If a community has an educational establishment running a health and social-care course (C), this could be a source of volunteers $(\mathrm{O})$, as students/trainees will have the drive and interest to work with social-care-related activities to gain experience (M). $[62,65,91,92,93]$

CMOC85: If a formal partnership is agreed with an educational establishment (C), this will guarantee regular volunteers during term time (O), as work placements can be formalised as part of students' courses (M). [65,92,93]

CMOC86: If the initiative is in a rural area $(C)$, then it can be more difficult to recruit volunteers $(0)$, as there may be no educational establishment or body of students/trainees to recruit from (M). [53,83]

CMOC87: If the initiative is in a rural area (C), then it may take more time to recruit volunteers $(\mathrm{O})$, as familiarity and personal contacts tend to be more important in small, close-knit communities (M). [83]

CMOC88: If the initiative is in a rural area (C), then it may be more difficult to recruit staff and volunteers $(\mathrm{O})$, as they may not live geographically near members or the venue, presenting extra logistical challenges (M). $[53,83]$

CMOC89: If a community has a population of active retirees (C), this could be a source of volunteers $(\mathrm{O})$, as they are likely to have time and experience conducive to volunteer work with older people (M). [56]

CMOC90: If there are friends and family of current or previous members/service users that are available (C), this could be a source of volunteers $(\mathrm{O})$, as they will understand the value of the intervention and already be invested in it $(\mathrm{M})$. [56,81]

CMOC91: If there are no specialist elements to the intervention or members with high care needs (C), then personnel do not need to have professional training or expertise $(0)$, as they will still be able to understand and deliver the intervention for the benefit for service users (M). [58,72]

CMOC92: If in intervention has more than one skilled facilitator (C), then it can benefit more members (O), as the workload can be split and more one-on-one support for members offered (M). [71,73,75]

CMOC93: If an initiative's leaders/co-ordinators have good communication and interpersonal skills (C), then it is more likely to be successful (O), as they will engage and inspire other staff and volunteers (M). [38,51,61,79] 
CMOC94: If volunteers' availability and interpersonal skills are inconsistent (C), an initiative is less likely to be successful $(\mathrm{O})$, as it will not have a reliable workforce to run it (M). [73]

CMOC95: If funded support worker roles exist (C), then a reliable volunteer workforce is more likely (O), because they can help build a volunteer base (M). [50]

\section{Keeping Staff and Volunteers}

CMOC 96: If personnel are flexible and open to new ways of working (C), then they are more likely to work effectively (O), as they will be more likely to collaborate with others, sharing knowledge, experience, innovation, resources and effective working practices (M). $[59,60,79,93]$

CMOC 97: If personnel have advice or training to boost communication and collaboration skills $(\mathrm{C})$, then they are more likely to work effectively $(\mathrm{O})$, as they will be more able to share knowledge, experience, innovation, resources and effective working practices (both internally and externally) (M). [60,76]

CMOC 98: If personnel are driven and able to deal with stress $(C)$, then they are more likely to continue $(O)$, as they will be able to overcome the challenges and demands of running an intervention (M). [61]

CMOC 99: If facilitators are not able to take time for self-care (C), then they will burn out $(\mathrm{O})$, as running an intervention can be challenging and emotionally demanding (M). [43,75]

CMOC 100: If time is taken to plan strategies for recruitment, training, support, retention and balance of personnel at the start (C), then personnel problems and burn out can be avoided $(\mathrm{O})$, as planners will have thought through the challenges involved and put in place actions to tackle them (M). [70,74]

CMOC 101: If personnel have access to experienced tips and guidance (from materials or individuals) throughout an intervention's start-up period $(\mathrm{C})$, they are more likely to continue $(\mathrm{O})$, as they will be better informed to resolve problems and avoid common pitfalls $(\mathrm{M})$. [37,56]

CMOC 102: If there is an ethos of inclusion, community, camaraderie and helping people (C), then personnel will be more likely to continue (O), as they will feel enjoyment and benefit from this ethos along with members/service users $(\mathrm{M})$. [52,58,75]

CMOC 103: If there are a range of roles and levels of involvement for volunteers (C), they are more likely to be satisfied with volunteering (O), as they can do something that suits them and their abilities that they are comfortable with and interested in (M). [84]

CMOC 104: If volunteers are included in professional activities and training $(C)$, they are more likely to be satisfied with volunteering $(0)$, as they will feel their skills and development are valued by the initiative (M). [38]

CMOC 105: If there is limited and inconsistent funding (C), then an intervention is less likely to be able to retain paid staff $(\mathrm{O})$, because their jobs and the long-term future of the intervention will not be secure (M). [73,79,84]

CMOC 106: If personnel roles are not secure (C), then an initiative is less likely to sustain (O), because turnover will be high and key individuals with key experience and contacts will be lost (M). [67,79,84]

CMOC 107: If volunteers are seen by authorities and commissioners as "coming for free" (C), then they are less likely to continue (O), as they will feel un-valued with their time and expertise taken for granted (M). [87]

CMOC 108: If unpaid volunteers are treated as a replacement for professional staff (C), then staff are less likely to continue (O), as they will feel their roles are undermined and un-valued (M). [51]

CMOC 109: If financial assistance is made available for volunteer groups (C), then they are more likely to continue (O), as they will have the resources and support to run more activities (M). [50]

\section{Getting Support of Other Organisations}

CMOC 110: If there is a higher public awareness and profile for people living with dementia (C), then dementia-targeted interventions are more likely to get support from other organisations, services and amenities $(\mathrm{O})$, because there will be more recognition of their importance for society in general (M). [39,84,90]

CMOC 111: If the added value of an intervention is made clear to other organisations (C), then it is more likely to get support and find a place in the local care offer $(0)$, because other organisations will understand it's value to their members/service users (M). $[41,42,50,54,55,61,75,79,86]$

CMOC 112: If an intervention engages with research and evaluation to gather evidence of benefits (C), then it is more likely to get support $(\mathrm{O})$, because the resulting reports will lend it legitimacy in the eyes of other organisations $(\mathrm{M})$. $[37,70,80]$

CMOC 113: If it is made clear that an intervention is based upon a strong evidence-based model (C), then it is more likely to get support (O), because that model will lend it legitimacy in the eyes of other organisations (M). [41,79,86]

CMOC 114: If an intervention involves the local community in its steering (C), then it likely to attract further community support (O), as key people and organisations in the community with wider links will feel a sense of ownership and investment (M). [84]

CMOC 115: When there are a range of organisations (e.g. local authority, third sector, faith, business and education) active in the community $(\mathrm{C})$, they may be willing to offer support if asked $(\mathrm{O})$, as they may have a remit to share resources such as venue space and facilities, equipment, training, staff, volunteers or contacts (M). [48,52,58,62,65,67,69,77,80,92,93] 
CMOC 116: If an intervention model is flexible (C), then it has a better chance of finding support (O), as it can accommodate being run at a range of venue types in, a range of ways, by a range of host organisations $(M)$. [69,71,72,75]

CMOC 117: If an existing social care business is approached (C), they may support, host or partner an intervention (O), as it may help them attract clients/customers (M). [75]

CMOC 118: If training and guidance is available from a public or third sector authority (C), this may help gain further support (O), as it will help an intervention develop its skills and expertise in marketing, networking and outreach (M). [46]

CMOC 119: If an intervention is based in a civic centre or public venue (C), then it is more likely to get support from other local organisations $(\mathrm{O})$, because it will be visible to others sharing that space $(\mathrm{M})$. [59,79]

CMOC 120: If an intervention focuses on building links with local organisations and services (C), it is more likely to get support (O), as it is easier to bring together a network of those who are already invested in the same community and some links will already exist (M). $[41,42,62]$

CMOC 121: If an intervention is run at a public venue or local club (C), then links with others in the community are easier to forge (O), as there will be an existing network of venue/club users and contacts that the intervention can access (M). [41,48,58,62]

CMOC 122: If a group or activity is small scale (C), then it can be hard to get support (O), as it is more difficult for them to network with larger organisations, authorities, movers and shakers (M). [77]

CMOC 123: If struggling groups in the same area merge (C), they can support each other $(\mathrm{O})$, because they can pool resources, personnel, knowledge and ideas (M). [67]

CMOC 124: If links are forged with a national network of similar interventions (C) then they can support each other (O), because they can pool resources, knowledge, contacts and strategy (M). [42]

CMOC 125: If a locality has other organisations working with the same target population (C), then in intervention may struggle to get support (O), as those other organisations and their supporters may perceive the intervention as competition (M). [41,79]

CMOC 126: If an intervention has a clear place in the local offer without service/role overlap (C), then it is more likely to get the support of others $(\mathrm{O})$, because they will see it as complimenting their service not competing with it $(\mathrm{M}) .[42,51]$

CMOC 127: If other organisations are informed, invited to meetings and asked for help and advice early on (C), then an intervention is more likely to get the support $(0)$, because they will feel respected and invested in the success of the new intervention $(M)$. [51,61,79,84]

CMOC 128: If groups involve professionals already working with individual members (e.g. case workers, carers) in activities (C) then they are more likely to increase support from professional services $(O)$, because professionals will understand the value of the intervention to their service-users and feel invested in its success (M). [79]

CMOC 129: If an intervention acts as a hub for/gate/link to other services and is tuned to dovetail with them (C), then it is more likely to get the support of those services $(0)$, because they will see the intervention as being of help to them $(M) .[42,60,61,72,86,88]$

CMOC 130: If an intervention offers a benefit or resource to the wider community (C), then it is more likely to get the support of other community organisations (O), as they will see it as benefiting their members/service users (M). $[41,46,67,70]$

CMOC 131: If an intervention offers to do reciprocal work, sharing knowledge and resources with other organisations (C), then it is more likely to get their support $(0)$, as they will see the benefit to working together $(M)$. [41,46,67,70]

CMOC 132: If there is a disjoin between national policy and local need (C), then initiatives can struggle to get and keep support (O) because by adhering to one they will neglect the other, alienating would-be supporters (M). [51]

CMOC 133: If there were ring-fenced funding to support dementia-targeted community initiatives as part of national policy (C), then small, local initiatives would get support $(O)$, as there would be incentives for health services and LAs to help them $(M)$. $[39,59,69]$

CMOC 134: If health and social care authorities commissioned services to work with community initiatives (C), then small, local initiatives would get support $(\mathrm{O})$, because it would ensure the collaboration of services and organisations at different levels $(\mathrm{M})$. [47,50,77]

CMOC 135: If health pathways were developed around existing social networks (C), then small, local initiatives would get support (O), as it would encourage more community collaboration and co-production with health services (M). [47]

CMOC 136: When national and official organisations take the lead in working with small, local initiatives (C), this helps more consistent provision of local services across regions $(\mathrm{O})$, because there is more joined-up strategic direction of what is on offer and available (M). $[39,50]$

CMOC 137: When national and official organisations show support for the involvement of private sector partners (C), then small, local initiatives are more likely to get support $(\mathrm{O})$, as it provides private sector organisations with the incentive, tools and guidance to work in partnership (M). [39]

\section{Keeping Support of Other Organisations}

CMOC 138: If communication is not maintained (C), then support of others can drop away (O), as interest and enthusiasm may dwindle in tandem with an intervention's contact and visibility to its collaborators (M). [41,55]

CMOC 139: If information sharing and knowledge transfer is not maintained (C), then support of others can drop away (O), as communication and administration problems may arise between collaborating parties (M). [44,45,77] 
CMOC 140: If there is a designated person with responsibility for regular and consistent communication with other organisations (C), then continued support is more likely $(0)$, as they will have the time to pay attention to maintaining collaborative working, and build experience and relationships with key people in doing so $(\mathrm{M}) .[41,50]$

CMOC 141: If relationships with key people in other organisations are maintained (C), then support of those organisations is more likely to continue (O), as an intervention will create "champions" within those organisations (M). [39,51]

CMOC 142: If staff turnover (internal and external) is high (C), then support can be lost (O), because communication and relationships with contacts and "champions" can suffer due to the loss of key personnel (M). [67,79,84]

CMOC 143: If there is a difference in culture between collaborating organisations (C), then effective support can be hindered (O), as personnel from each organisation will not be working with the same focus and goals (M). [41,51,79]

CMOC 144: If groups or sectors have a negative or competitive attitude towards each other (C), then effective support can be hindered (O), as it creates problems sharing data, learning and resources $(\mathrm{M}) .[41,76,77]$

CMOC 145: If an intervention makes effort to learn about and embed in the life of a supporting organisations (C), then it is more likely to maintain support $(\mathrm{O})$, as it will understand that host organisation better and share the same goals (M). [70]

CMOC 146: If staff (internal and external) are experienced in working collaboratively (C), then an intervention is more likely to maintain support (O), as staff will be more skilled, flexible and understanding when working with those from another organisation (M). [79]

CMOC 147: If independent advice on communication (internal and external) and collaboration is available (C), then an intervention is more likely to maintain support (O), as leaders, staff and volunteers will become more skilled at networking and working together while overcoming differences in culture (M). [60,79]

CMOC 148: If there are multiple forms of strong inter-professional leadership (C), then collaboration is likely to be more successful (O), because there will be mutual learning with leaders setting an example for others to follow (M). [51,59,79,86]

CMOC 149: If time is taken to plan well early on (C), then support from others is more likely to be maintained (O), as personnel will have thought through the challenges involved in maintaining energy and enthusiasm and put in place actions to tackle them (M). [70]

CMOC 150: If there is a steering group including outside organisations (C), then support is more likely to be maintained (O), as steering will include a focus on shared agenda and complementarity with outside organisations (M). [51]

CMOC 151: If a partnership is not equal and collaborating at all stages, from planning to practice (C), then this could hinder support (O), as one party may feel the other is not contributing what it should while the other feels dictated to, creating friction $(\mathrm{M})$. [44,45]

CMOC 152: If a collaboration protocol with supporting organisations is drafted and discussions logged and reviewed (C), then support is more likely to be maintained $(\mathrm{O})$, because all parties will have the chance air and resolve issues and have clarity over expectations and mutual goals (M). [41,44,45,61,70]

\section{Getting Funding and Income}

CMOC 153: If potential funders are not clear on what a service/intervention is and does (C), then they will be less likely to fund it (O), because they do not understand its purpose or value (M). [89]

CMOC 154: If potential funders are made aware of the added value and benefit of an intervention (C), then they will be more likely to fund it (O), because they will recognise it has something uniquely valuable to offer service users $(\mathrm{M})$. [61,70]

CMOC 155: If communication and publicity is regularly disseminated to potential funders (C), then they are more likely to fund in the future (O), as they will be familiar with and alert to the work of an intervention (M). [94]

CMOC 156: If recognised and standardised materials (e.g. Alzheimer's Society materials, PQASSO or Social Return on Investment evaluation) are used to gather and communicate evidence of worth $(\mathrm{C})$ then funders are more likely to fund $(\mathrm{O})$ as they will see that evidence as more legitimate than anecdotal accounts (M). [80]

CMOC 157: If potential funders are made aware of links with and support from other organisations (C), then they're more likely to fund (O) because they are likely to view the support of others as adding legitimacy to a community initiative (M). [70]

CMOC 158: If corporate organisations are made aware of how an intervention aligns with its aims (C), then they will be more likely to sponsor or donate $(\mathrm{O})$, as they will feel supporting that intervention helps progress their goals (M). [94]

CMOC 159: If an intervention develops its skill in networking and communicating with other organisations (C), then it is more likely to find funding $(\mathrm{O})$, as it will learn of funding opportunities through a wider network of support and contacts (M). [46]

CMOC 160: If awareness of the wants and needs of people with dementia is raised in society in general (C), then funders are more likely to support a dementia-targeted initiative $(0)$, as they are more likely to recognise that it meets the needs of service-users $(M)$. $[39,46]$

CMOC 161: If there is demand for an intervention from service users and referrers (C), then funders are more likely to fund (O), as they will recognise that it is meeting people's needs (M). [46]

CMOC 162: If potential members/service users are not clear on what a service/intervention is and does (C), then they will be less likely to try it $(0)$, because they do not understand it's purpose or value to them $(\mathrm{M}) .[41,51,56,89]$

CMOC 163: If potential referrers are not clear on what a service/intervention is and does (C), then they will not refer people to it (O), because they do not understand its purpose or value to their service users (M). [41,51,61,75,79] 
CMOC 164: If an intervention is perceived as more expensive than alternatives on offer without offering significant added value (C), funders will be less likely to fund (O), as they will not see it as value for money (M). [79,80,87,95]

CMOC 165: If an initiative is perceived as having financial difficulties $(C)$, potential funders are less likely to fund $(0)$, as they will see it as a high risk funding decision (M). [56,61]

CMOC 166: If an initiative has co-operative working arrangements with other community organisations (C), then this can help keep costs low $(0)$, as they can agree to share resources (venue, personnel, equipment, training etc.) (M). [70,75,76,78,80,93]

CMOC 167: If an initiative can generate some income through offering services to others $(C)$, then funders are more likely to have confidence in it (O), as they will perceive it be to more viable (M). [94]

CMOC 168: If funders are made aware of the support from other organisations for a new initiative (C), they are more likely to fund $(\mathrm{O})$, as they will perceive the initiative as being more viable due to that support (M). [70]

CMOC 169: If initiative can act as a gate/link for other services and community organisations (C), then it is more likely to get funding (O), as it will be seen as of value to enhancing existing services and organisations (M). [60,61]

CMOC 170: If intervention personnel have good, up-to-date knowledge of funding processes and policy (C), they are more likely to get funding $(0)$, because they will understand how to plan and implement an effective strategy to seek and find it $(M)$. $[55,61,86]$

CMOC 171: If like-minded groups share successful ideas (C), they are more likely to find funding solutions (O), because they will be able to learn from each other about what works or doesn't work (M). [80,91]

CMOC 172: If interventions include more practical detail on resources, costs and funding as part of standard reporting/evaluation (C), then others in the future will be more likely to find funding solutions $(\mathrm{O})$, as they can learn from the experience of others about what works or doesn't work (M). [37]

CMOC 173: If authoritative help is available to develop personnel's expertise regarding business planning and networking (C), then an intervention is more likely to find funding solutions $(\mathrm{O})$, because personnel will be better at developing and implementing a strategy to do so (M). [46]

CMOC 174: Ifan intervention has a realistic strategy to attract donations and grants (C), then it is more likely to find funding solutions (O), as personnel will have thought through the challenges involved and put in place actions to tackle them (M). [94]

CMOC 175: If an intervention has a business case ready (C), then it is more likely to secure funding $(0)$, as it will be able to respond quickly when a window of opportunity opens with a potential funder (M). [60]

CMOC 176: When an initiative is in a more rural area (C), it is likely to be small scale with fewer members/service users (O), because the population is geographically diffuse without the infrastructure to gather together easily (M). [84]

CMOC 177: If an initiative is small-scale (C), it will not be able to robustly demonstrate demand, effectiveness and H\&SC savings (O), because it's number or members/service users will not be enough to capture robust evidential statistics (M). [84]

CMOC 178: If funders demand robust statistical evidence before funding (C), then small and rural groups and activities will be disadvantaged $(\mathrm{O})$, because they will not have the numbers and resources to produce this $(\mathrm{M})$. [50,84,91]

CMOC 179: If an initiative is small-scale (C), it will be disadvantaged in securing funding (O), as it will have fewer personnel with more limited time and resources to continually apply (M). [84]

CMOC 180: If an intervention is aligned with national agenda $(C)$, then it is more likely to get funding $(0)$, because the policy and infrastructure will be in place to support it (M). [42,55,59,84]

CMOC 181: If national policy is not consistent with local need (C), then local groups serving those needs will struggle to attract funding (O), as funders will not see their cause as a priority (M). [41,51,84]

CMOC182: If the national (and by extension funders') agenda focuses on medical needs and costs over social and emotional needs (C), then community-focussed groups and activities will struggle to get funding $(0)$, as funders will not understand their benefits or see their cause as a priority (M). [77,80,86,91,95]

CMOC 183: If intervention providers, service users and families speak out about their needs (C), providers may be more likely to get funding for local community-focussed services $(\mathrm{O})$, as authorities will feel pressure to change the national agenda to meet people's needs (M). [96]

CMOC 184: If resources are not allotted and ring-fenced to match changes in national or local policy (C), there will be no benefit to community interventions $(\mathrm{O})$, as funders will not have the resources to invest in making a difference in practice $(\mathrm{M}) .[39,50,76,87]$

\section{Keeping Funding and Income}

CMOC 185: If communication and publicity is regularly disseminated to funders (C), then they are more likely to fund again in the future (O), as they will be kept informed and alert to the continuing work and benefits of an intervention (M). [94]

CMOC 186: If publicity and networking is pared back to cut costs (C), this could negatively impact changes of finding continued funding (O), as an intervention will drop off funders' "radar" and risk being forgotten or overlooked (M). [94]

CMOC 187: If funders are made aware of a growth in demand for an intervention from service users and referrers (C), then they are more likely to continue to fund $(0)$, as they will recognise that it is meeting people's needs $(M)$. [46,55] 
CMOC 188: If funders are made aware of accruing evidence of the added value and benefit of an intervention (C), then they will be more likely to fund it $(O)$, because they will recognise it has something uniquely valuable to offer service users $(\mathrm{M})$. [61,70]

CMOC 189: If groups and organisations do not communicate and work together (C), then existing funds will not go as far (O), as available financial resources will be split and lost on inefficiencies and duplication of services (M). [76]

CMOC 190: If an initiative has co-operative working arrangements with other community organisations (C), then this can help keep costs low $(0)$, as they can agree to share resources (venue, personnel, equipment, training etc.) (M). [70,75,76,78,80,93]

CMOC 191: If an initiative has multiple and diverse income streams (C), then it is more likely to maintain a proportion funding (O), because if one stream stops, others will still be available. $[70,80,84]$

CMOC 192: If an initiative's budget is broken down into identified parts (C), then it is more likely to be able to weather changes in funding (O), as what can be used to pay for what is more flexible, and core activity can be prioritised (M). [70,84,94]

CMOC 193: If financial planning is done with a focus on the long-term (C), then an initiative is more likely to weather changes in funding (O), as it will be able to spread existing funds more effectively by allotting spending carefully $(\mathrm{M}) .[44,45,70]$

CMOC194: If an intervention has a realistic strategy to continually attract donations and grants (C), then it is more likely to find funding solutions (O), as personnel will have thought through the challenges involved and put in place actions to tackle them (M). [94]

CMOC 195: If there is no long-term funding available (C), this will place significant demands on the time and resources of personnel (O), because they will need to continually seek and apply for fresh funding (M). [84]

CMOC 196: If an initiative is small-scale (C), it will be disadvantaged in continuing to secure funding (O), as it will have fewer personnel with more limited time and resources to continually seek and apply (M). [84]

CMOC 197: If an initiative continually and systematically seeks new income streams (C), then it is more likely to maintain a proportion funding $(\mathrm{O})$, because if one stream stops, it will be more likely to have multiple other streams available $(\mathrm{M}) .[70,80,84]$

CMOC 198: If funders objectives are always short-term and keep changing $(C)$, then deep learning on what works for services users and communities will be lost (O), as "quick win" projects will be encouraged over support for existing and experienced initiatives (M). [51,79]

CMOC 199: If funders only support short-term or new projects (C), then initiatives will struggle to become established long-term (O), as they will be unable to plan ahead with confidence or have time to learn how activity can be supported sustainably $(\mathrm{M})$. [77,86,87]

CMOC 200: If resources are not allotted and ring-fenced to match changes in national or local policy (C), there will be no benefit to community interventions $(O)$, as funders will not have the resources to invest in making a difference in practice $(\mathrm{M}) .[39,50,76,87]$

CMOC 201: If intervention providers, service users and families speak out about their needs (C), providers may be more likely to get funding for local community-focussed services $(0)$, as authorities will feel pressure to change the national agenda to meet people's needs (M). [96] 